Andrews University

Digital Commons @ Andrews University

Master's Theses

Graduate Research

1987

\title{
A Comparison of the Television Viewing Habits of Religiously Oriented and Non-Religiously Oriented Children
}

Hector C. Detres

Andrews University, detresh@andrews.edu

Follow this and additional works at: https://digitalcommons.andrews.edu/theses

Part of the Educational Psychology Commons

\section{Recommended Citation}

Detres, Hector C., "A Comparison of the Television Viewing Habits of Religiously Oriented and NonReligiously Oriented Children" (1987). Master's Theses. 146.

https://dx.doi.org/10.32597/theses/146

https://digitalcommons.andrews.edu/theses/146

This Thesis is brought to you for free and open access by the Graduate Research at Digital Commons @ Andrews University. It has been accepted for inclusion in Master's Theses by an authorized administrator of Digital Commons@Andrews University. For more information, please contact repository@andrews.edu. 
A COMPARISON OF THE TELEVISION VIEWING HABITS OF RELIGIOUSLY ORIENTED AND NON-RELIGIOUSLY ORIENTED CHILDREN

by

Hector Detres C.

Chairman: Lenore S. Brantley 


\section{ABSTRACT OF GRADUATE STUDENT RESEARCH}

Thesis

Andrews University

School of Education

Title: A COMPARISON OF THE TELEVISION VIEWING HABITS OF RELIGIOUSLY ORIENTED AND NON-RELIGIOUSLY ORIENTED CHILDREN.

Name of researcher: Hector Detres C.

Name and degree of faculty adviser: Lenore S. Brantley, Ed.D.

Date completed: August 1987

\section{Problem}

Television plays an important role in the lives of children. The objective of this study was to compare religiously oriented and nonreligiously oriented children and the patterns of television viewing habits between these two groups.

\section{Method}

The analysis of variance was used to measure the hypotheses. A questionnaire completed by 378 subjects in grades $3,6,9$, and 12 in private and public schools was used to gather the data for this study. 
Results

Significant differences were found between religiously oriented and non-religiously oriented children in the average number of hours of television viewing, and in preference for crime-action and educationalaltruistic programs by grade levels. No significant differences were found between grade level and the number of hours of television viewing and preference towards crime-action and educational-altruistic programs between the two groups.

\section{Conclusions}

This study has provided some information about trends in television habits between religiously oriented and non-religiously oriented children. 
Andrews University

School of Education

A COMPARISON OF THE TELEVISION VIEWING HABITS OF RELIGIOUSLY ORIENTED AND NON-RELIGIOUSLY ORIENTED CHILDREN

\author{
A Thesis
}

Presented in Partial Fulfillment

of the Requirements for the Degree

Master of Arts

by

Hector Detres C.

September 1987 

A COMPARISON OF THE TELEVISION VIEWING HABITS OF RELIGIOUSLY ORIENIED AND NON RELIGIOUSLY ORIENTED

CHILDREN

A thesis

presented in partial fulfillment of the requirements for the degree

Master of Arts

by

Hector Detres C.

APPROVAL BY THE COMMITTEE:
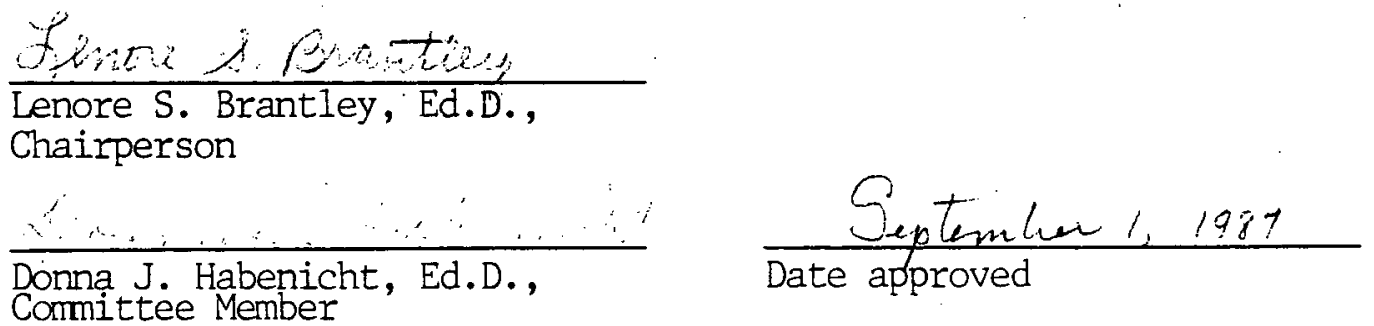
TABLE OF CONTENTS

LIST $\mathrm{OF}$ TABLES $\ldots \ldots \ldots \ldots \ldots \ldots \ldots \ldots \ldots \ldots \ldots \ldots \ldots \ldots \ldots \ldots \ldots$

ACKNOWLEDGMENTS $\ldots \ldots \ldots \ldots \ldots \ldots \ldots \ldots \ldots \ldots \ldots \ldots \ldots \ldots \ldots \ldots \ldots \ldots$ vii

Chapter

I. INTRODUCTION $\ldots \ldots \ldots \ldots \ldots \ldots \ldots \ldots \ldots \ldots \ldots \ldots \ldots \ldots$ 1

Background of the Problem $\ldots \ldots \ldots \ldots \ldots \ldots \ldots \ldots \ldots$.

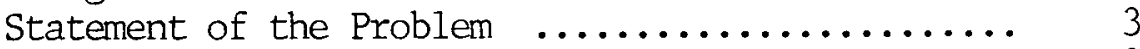

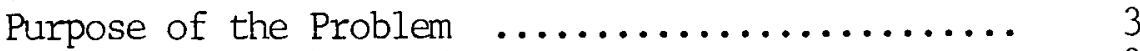

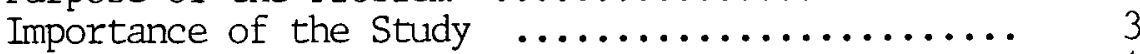

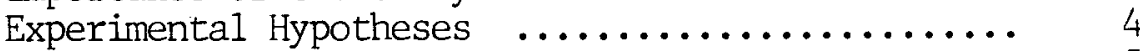

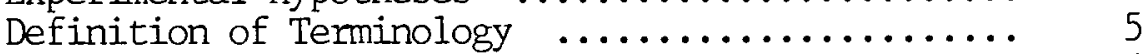

Organization of the Study $\ldots \ldots \ldots \ldots \ldots \ldots \ldots \ldots \ldots$

II. REVIEW OF THE LITERATURE $\ldots \ldots \ldots \ldots \ldots \ldots \ldots \ldots \ldots$

Effects of Television on Children $\ldots \ldots \ldots \ldots \ldots .7$

Cartoon Violence and Children's Aggression ...... 12

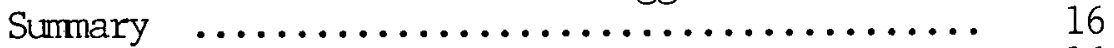

Auditory vs. Visual Effects of Television ...... 16

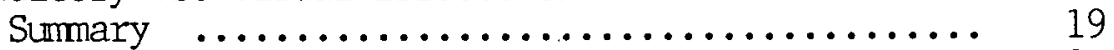

Prosocial Behavior and Television $\ldots \ldots \ldots \ldots \ldots .20$

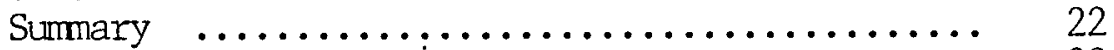

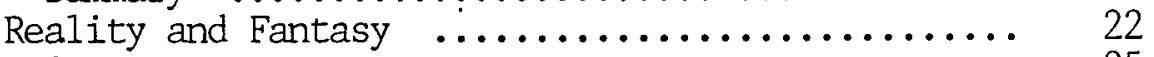

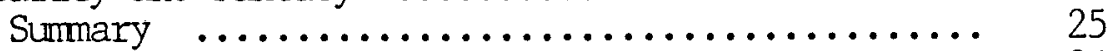

Later-in-Life Effects of Television $\ldots \ldots \ldots \ldots \ldots .26$

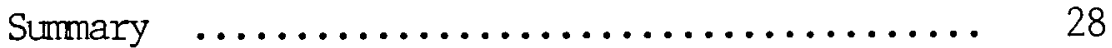

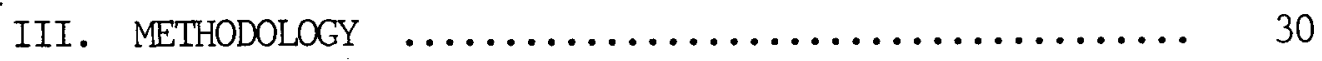

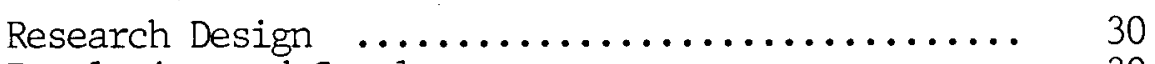

Population and Sample $\ldots \ldots \ldots \ldots \ldots \ldots \ldots \ldots \ldots . . . \ldots \ldots \ldots \ldots \ldots \ldots$

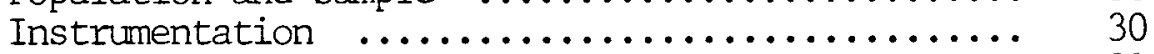

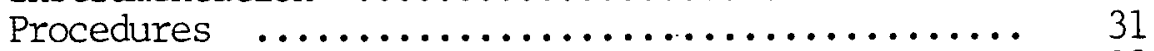

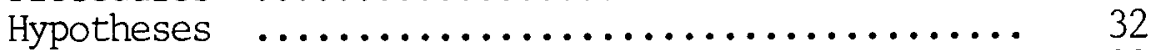

Dependent Variable $\ldots \ldots \ldots \ldots \ldots \ldots \ldots \ldots \ldots \ldots . \ldots \ldots \ldots \ldots$

Independent Variable $\ldots \ldots \ldots \ldots \ldots \ldots \ldots \ldots \ldots \ldots . \ldots \ldots \ldots$

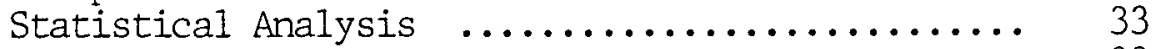

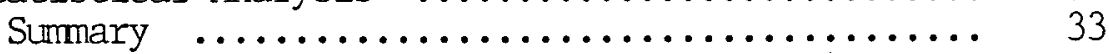




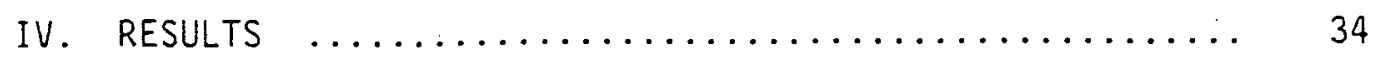

Profile of the Study Subjects ............... 34

Description of Hypothesized Relationships ........ 35

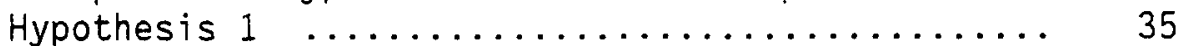

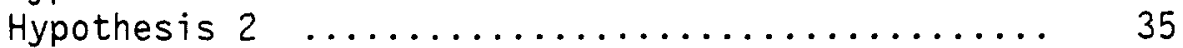

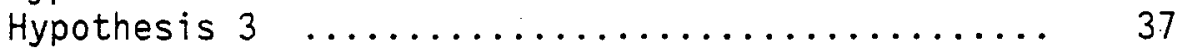

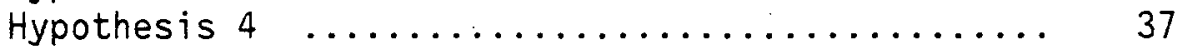

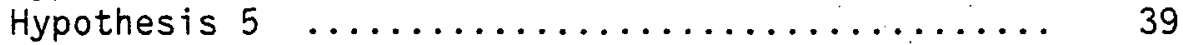

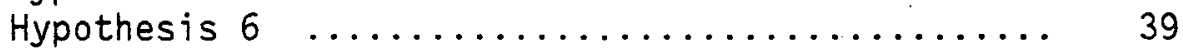

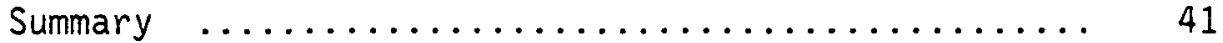

V. SUMMARY, CONCLUSIONS, AND RECOMMENDATIONS $\ldots \ldots \ldots \ldots .42$

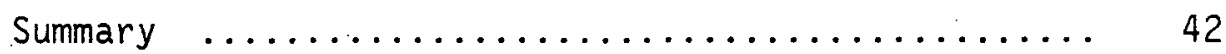

Statement of the Problem $\ldots \ldots \ldots \ldots \ldots \ldots \ldots . \ldots \ldots, 42$

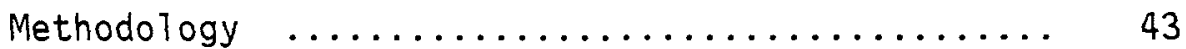

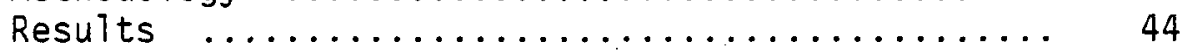

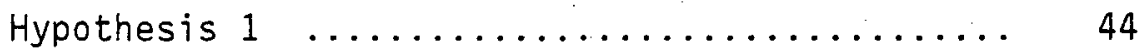

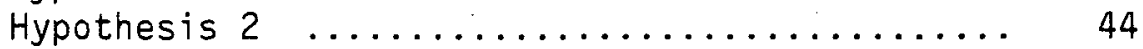

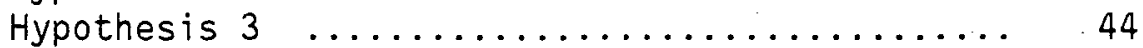

Hypothesis 4 ......................... 44

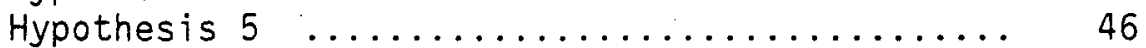

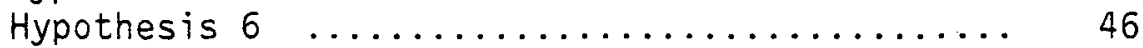

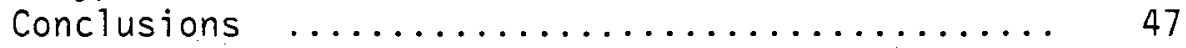

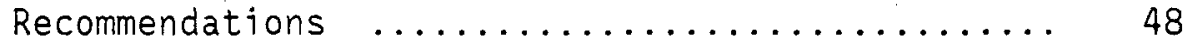

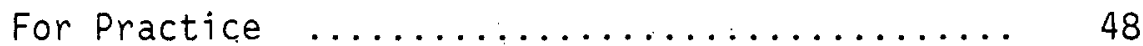

For Further Research $\ldots \ldots \ldots \ldots \ldots \ldots \ldots \ldots . \ldots \ldots$

APPENDICES $\quad \ldots \ldots \ldots \ldots \ldots \ldots \ldots \ldots \ldots \ldots \ldots \ldots \ldots \ldots \ldots \ldots \ldots \ldots \ldots \ldots \ldots$

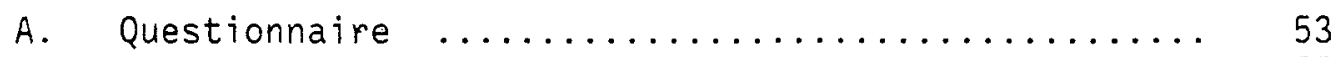

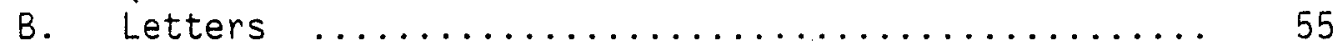

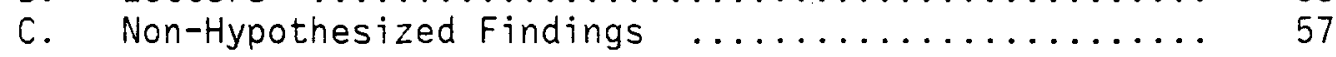

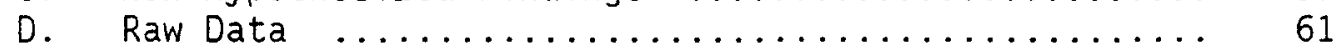

REFERENCES $\ldots \ldots \ldots \ldots \ldots \ldots \ldots \ldots \ldots \ldots \ldots \ldots \ldots \ldots$ 
LIST OF TABLES

1. Hours of Television Viewing Per Day $\ldots \ldots \ldots \ldots \ldots \ldots . \ldots 36$

2. Analysis of Variance--Orientation by Grade Hours of Television Watched $\ldots \ldots \ldots \ldots \ldots \ldots \ldots . . . . .6$

3. Crime-Action Television Preference $\ldots \ldots \ldots \ldots \ldots \ldots . \ldots 38$

4. Analysis of Variance--Orientation by Grade Crime-Action Television Hours ................ 38

5. Educational-Altruistic Television Preference $\ldots \ldots \ldots \ldots 40$

6. Analysis of Variance--Orientation by Grade

Educational-Altruistic Television Programs by Grade

7. Religious Orientation by Grades ............... 58

8. Non-Religious Orientation by Grades $\ldots . \ldots \ldots \ldots . \ldots . \ldots 58$

9. Hours of Video Viewing Per Week $\ldots . . . \ldots . . . . . . . .59$

10. Video-Movies Preference $\ldots \ldots \ldots \ldots \ldots \ldots \ldots \ldots \ldots \ldots . \ldots . \ldots$

11. Parental Involvement in Television Control .......... 60

12. Sample by Grades and Schools ................... 60 
ACKNOWLEDGMENTS

I want to express my sincere gratitude to those who contributed to the realization of this paper.

First of all, to God who gave me the courage to go beyond my strengths and who faithfully supported me through my studies.

To my parents, Hector and Carmen, for trusting me in: pursuing a master's degree.

To Dr. Lenore Brantley who worked side by side with me to make this thesis paper come true.

To Dr. Donna Habenicht who gladly served as a member of the committee.

To Dr. Wilfred Futcher who graciously contributed to the statistical expertise.

Finally, to my wife Elizabeth and my beautiful daughter Jennifer who always contributed to my psychological, spiritual, and physical well being. They always were there to encourage me and to trust in my efforts. 
CHAPTER 1

INTRODUCTION

In 1983 Americans watched 213 billion hours of television (TV). Over $65 \%$ of our population can no longer remember the era before television. With American children averaging between 2 and 3 hours of television viewing daily throughout their childhood, television becomes an extremely powerful agent of socialization that can inculcate either undesirable social lessons (Poulos, Harvey, \& Liebert, 1975) or positive social lessons (McCoy, 1981).

The amount of television viewing also affects school achievement and displaces reading activities, although this conclusion is not well established. Other possibilities such as "interference" between reading skills and television viewing skills are poorly understood (Hormick, 1981).

The Surgeon General of the United States (U.S. Department of Health and Human Services, 1972) concluded that "television violence is as strongly correlated with aggressive behavior as any other behavioral variable that has been measured" and that children learn to behave aggressively from the violence they see on television in the same way they learn cognitive and social skills from watching their parents, siblings, peers, teachers, and others.

Cartoons also affect human behavior, especially in children. Researchers such as Stein and Friedrich (1975) concluded that "at this 
stage, there is no reason to think that cartoons have less effect than films of peop 1e." Gerbner (1972) pointed out that $80-90 \%$ of all programs contained violence, with children's cartoons containing the greatest amounts.

Although media officials have claimed that parents can effectively control the adverse effect of TV programming by talking to their children, few studies have been found on this topic. Fontes (1978) demonstrated that condemnation by mothers and non-related adult females of televised violence heightened children's perceptions of such incidents as inappropriate but did not otherwise influence children's aggressive or cooperative behavior.

Mattern and Lindholm (1983) conducted an experiment to extend and refine Fontes' research. Subjects were 12 boys and girls ranging in age from 61 to 73 months and their mothers. These children watched 10-minute segments from a popular TV series called "The Incredible Hulk" (copyright by CBS) characterized by its violence. Boys and girls were randomiy assigned to treatment and nontreatment groups.

Treatment mothers were given a description of what they were to see and suggestions for anti-aggressive comments that they might say while looking at the program. Nontreatment mothers were asked on ly to watch the show with their children.

The results showed a tendency for treatment boys to be more helpful and less aggressive than nontreatment boys and for treatment girls to be less helpful and more aggressive than nontreatment girls (pp. 133-134). 
Poulos, Harvey, and Liebert (1976) studied the programming of the main TV networks. They found that the heaviest amount of violence and aggressiveness is on Saturday morning cartoons. McCork le (1980) also connected Saturday cartoons as the "language ghetto," meaning that the cartoons contained the greatest amount of aggressive language.

\section{Statement of the Problem}

The American child spends 3 to 5 hours a day watching TV. One of the most important concerns of parents and educators today is the influence of television on the behavior of children. Numerous studies have verified this relationship. The purpose of this study was to determine if a religious orientation has some effect upon the television-viewing habits of children.

\section{Purpose of the Study}

The purpose of this study was to find if a significant difference existed between religiously oriented children and nonreligiously oriented children in the pattern of television viewing in the areas of content (educational-altruistic and crime-action) and time (hours watching TV) and to find if this pattern continued or changed from the 3 rd to 12 th grades. Specific areas of study included:

1. Hours of watching TV per day

2. Types of TV programs and their preferences based on content:
a) altruistic and educational
b) crime-action 
Importance of the Study

To date no research studies have been conducted showing the relationship between television viewing and the extent of religious activities. Studies are needed in this area to determine if religious orientation has a direct influence upon the children's televisionviewing habits. The information offered in this study will provide valuable information for professionals working with children and ado lescents.

\section{Experimental Hypotheses}

The following hypotheses were tested:

1. There is a significant difference between religiously oriented children and non-religiously oriented children in hours per day viewing television.

2. There is a significant difference between religiously oriented and non-religiously oriented children in the number of hours of television viewing at different grade levels.

3. There is a significant difference between religiously oriented and non-religiously oriented children in the number of hours of viewing crime-action programs on television.

4. There is a significant difference between religiously oriented and non-religiously oriented children in the number of hours weekly viewing crime-action television programs at different grade Tevels.

5. There is a significant difference between religiously oriented and non-religiously oriented children in the number of hours of viewing educational-altruistic programs on television. 
6. There is a significant difference between religiously oriented and non-religiously oriented children in the grade levels and the number of hours of viewing educational-altruistic programs on television.

\section{Definition of the Terminology}

Altruism--Ethical principle which stresses and assumes positive value as an individual regard for the welfare of others.

Desensitization--The psychological process whereby, because of the heavy and continuous exposure to a stimulus, it becomes impossible for the viewer to model the novel response displayed by imaginary characters in imaginary situations. This creates a mental immunity to the horror of violence, which is now perceived as being normal.

Non-religiously oriented children--Defined as those who do not attend church regularly and who do not meet at least one of the following criteria:

a) have daily family worship at home

b) spend some time personally reading the Bible

c) engage in other religious activities.

Religiously oriented children--Defined as those who attend church regularly and, in addition, meet at least one of the following criteria:

a) have daily family worship at home

b) spend some time personally reading the Bible

c) engage in other religious activities.

Stereotype--Unreal and unchangeable ideas about the way men, women, and other races behave. 
Violence--The purposeful, illegal infliction of pain for personal gain or gratification that is intended to harm the victim and is accomplished in spite of social sanctions against it but is not limited solely to physical behavior. Violence can also be conceptualized to include non-physical behavior resulting in social or mental injury, such as damage to one's self-concept or to one's reputation.

\section{Organization of the Study}

Chapter 2 surveys the review of the literature. Chapter 3 explains the methodology, the type of research, the population and sample, the instruments used, and the method of statistical analysis and procedure. Chapter 4 covers the results, and Chapter 5 includes the summary, conclusion, and recommendations. 
CHAPTER 2

\section{REVIEW OF RELATED LITERATURE}

\section{Effects of Television on Children}

There has been a grave and growing concern over the question of whether the media--particularly television--may be encouraging violence and other antisocial behavior among children and youth. The Surgeon General of the United States appointed an advisory committee on television and social behavior that studied the matter from 1969 to 1971. They reported that the scientific data were not conclusive whether television violence causes aggression in most children, although they added that there was good evidence to indicate a relation between violence on television and aggressive behavior among children who already had a tendency toward aggressive behavior (U.S. Public Health Service, 1972).

A later review of research (Comstock, 1977) indicated that effects are largely dependent on situational factors such as "frustration or anger; similarities between the available target and the target in the portrayal; expected consequences such as success, failure, pain, or punishment; and opportunity to perform the act of violence" ( $p$. 195).

Ten years after the Surgeon General's 1972 report, however, a committee of behavioral scientists (U.S. Department of Health and Human Services, 1982) reviewed subsequent research for the National Institute of Mental Health and concluded that a relationship between viewing of 
violence on television and aggressive behavior in children was now well established.

The committee further concluded that "television violence is as strongly correlated with aggressive behavior as any other behavioral variable that has been measured," that the percentage of programs containing violence has been stable since 1967 although the number of violent acts per program has increased, and that children "learn to behave aggressively from the violence they see on television in the same way they learn cognitive and social skills from watching their parents, siblings, peers, teachers, and others" (pp. 6, 38, 39).

There is even more concern on the part of some critics about the sexual explicitness of television and of current movies. It is claimed by some that these media are causing pervasive changes in the customs and values of the society, while others argue that the social mores were already changing toward freer sexual and aggressive behavior and that the contemporary movies are simply satisfying the changing tastes of the public.

A book by Lawrence Alloway (1972) defending violence in the movies supports this latter conclusion. It is, of course, to be noted that the most violent and sexually explicit movies are supposed to be barred to the view of persons under 18 years.

That the media can be an important force for positive socialization is also apparent and has been supported by research indicating that "Sesame Street" has been helpful both for middle-- and lower-status children (Almedia, 1977; Leifer, Gordon \& Graves 1975), and that children can become more cooperative and nurturant after viewing

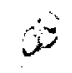


programs emphasizing these behaviors (Poulos, Reubenstein, \& Liebert, 1975)

Recognizing the promise as well as the potentially damaging effects of television on children and youth, critics have been organizing to promote changes in commercial programming in the United States. The Parent Teachers Association has made reform in television one of its principal national demands. Groups such as the National Citizens Committee for Broadcasting have been organized to collect data and lobby for change.

Critics of television have blamed it for a variety of social ills including the promotion of unintelligent consumerism, declining performance on academic tests in the schools, and the promulgation of stereotypes regarding low-status minorities (Pierce, Caren, \& Willis, 1977 ) and women. Winn (1977) presented some evidence and strong arguments that television may be making children physically and intellectually passive, with detrimental effects on their cognitive and academic development.

Research on the relationship between television viewing and school achievement indicates that a relationship exists, but evidence of television-viewing effects is limited mainly to reading and the causes of the relationship are somewhat unclear. A few studies suggest that television viewing may displace reading activities, but this conclusion is not well established and other possibilities such as "interference" between reading skills and television-viewing skills are poorly understood (Hormik,. 1981).

In any case, the overall negative relationship (i.e., more hours of viewing are associated with lower reading achievement) is not 
very large, and lowered achievement appears to be characteristic primarily of youngsters who report unusualiy frequent or "excessive" viewing--perhaps an average of 5 to 6 hours or more per day. However, given that most studies are correlational rather than experimental, one could equally speculate that students whose reading achievement is very low might tend to retreat to the television set.

Research indicates that relationships between achievement, television viewing, age of the student, home environment, and other variables are complex and multidimensional. For example, a 1981 study of television viewing among more than 12,000 sixth graders in California indicated that heavy viewing was associated with lower achievement in reading, mathematics, writing, lower social class, and preference for light entertainment. Viewing in excess of 5 to 6 hours per day was associated with low achievement for all social class groups; but for students of lower social class, watching television up to 3 to 4 hours per day was associated with lower achievement (California Assessment Program, 1982).

Preliminary findings from a 1982 survey by Bachan, Hornby, Roberts, and Hernandez-Ramos of 580 students in northern California further indicated that social class is more strongly related to reading achievement among third graders than sixth graders, and effects of viewing on achievement depend on such considerations as reasons for viewing (e.g., to learn or to escape from other activities), reasons for reading, and degree and type of "involvement" in reading and television viewing. The investigators concluded that "amount of viewing and amount of reading, although important variables in their 
own right, are but parts of a larger complex of related television or viewing constructs" (p. 194).

The television industry has not been completely unresponsive to criticism. Between 1975 and 1983, there was a slight reduction in violence and other adult themes during prime viewing hours, and efforts were being made to portray the antisocial nature of violence more meaningfully. The major networks also slightly reduced the number of commercials on Saturday morning cartoons for children and began to include more messages of social value as part of programs for children (Levine \& Havighurst, 1984, p. 194).

A study conducted by CBS in 1977 showed that 9 out of 10 children received at least one positive message from programs such as "Fat Albert and the Cosby Kids," "Shazam," and "Isis." However, Turrow (1981) reviewed three decades of network television programming for children and reported that criticism of the television industry has been ineffective at changing basic programming criteria, though it has "eked out" some concessions resulting in "slightly fewer actionadventure series, a few more live-action shows, a few more realistic dramas about children, [and] more children of both sexes in the programs" (p. 12). He also concluded that cable television is beginning to show some of the same deficiencies in programing for children as did network television in its early days.

A11 things considered, the effects of television on children and the family still pose an important national problem, though little can be concluded beyond the truism that television promises extraordinary benefits for education but also sometimes undermines 
family interaction and other forms of learning, such as play and reading. Violence on television may also have an affect upon children's aggressive behavior.

\section{Cartoon Violence and Children's Aggression}

The general conclusion of some research (Stein \& Friedrich, 1975) shows that viewing violence increases rather than decreases the aggressive behavior of the viewer. Researchers have also concluded that "At this stage, there is no reason to think that cartoons have less effect than films of people" (p. 222). A careful examination of published research reveals that there is evidence to support the view that fictional cartoons have considerable impact on children.

By 1967 Gerbner was reporting an all-time high of aggression: $80-90 \%$ of all programs contained violence, with children's cartoons containing the greatest amounts (Gerbner, 1972). This level of televised violence remained stable with little promise of change until the 1972 Senate Hearings on the issue. Responding to the Surgeon General's comprehensive report ( $C$ isin, 1972), network executives testified that amounts of TV aggression would decline, particularly in children's viewing hours. For example, Elton $\mathrm{H}$. Rule of the American Broadcasting Company stated:

Now that we are reasonably certain that televised violence can increase aggressive tendencies in some children, we will have to manage our program planning accordingly. (p. 197)

Poulos (1976) and her colleagues conducted a study to verify whether, indeed, there was such a change as reported by CBS in the children's cartoons. She recorded 72 programs directly off the air from the main TV stations: $A B C$, CBS, and NBC. She concluded, "It is 
clear that the majority of programs continue to feature aggressive content and many still focus on aggression as their central theme" ( $p$. 1056). In fact, a large number of the shows were remarkably high in aggression, averaging at least one aggressive act every two minutes.

Part of the problem with studying the effects of violence is the hazy definition of the actual term. George Gerbner (1972), who studied trends in violence, defined violence this way:

Violence connotes a great variety of physical and mental violations, emotions, injustices, and transgressions of social and moral norms. It is the overt expression of physical force against others or the compelling of overt action against one's will on pain of being hurt or killed. (p. 31)

Cartoons fall within this definition. Cartoon characters are constantly being flattened, beaten, run over, or blown up, leaving the character without any visible damage.

Once again, Gerbner (1972) reported that "Saturday morning cartoons have the heaviest saturation of violence on all television with one violent episode every two minutes" (p. 44). All of this violence is broadcast to 17.65 million children between 9:30 a.m. and 12:00 noon Saturday mornings.

A few years ago (1978) the "cathars is theory" was popular. This reassuring theory asserted that seeing violence is a useful outlet for aggression. Children release their anger and self-doubts by watching others act out violent situations. However, Victor Cline (1976), a University of Utah professor of psychology, said, "Seeing violence stimulates children aggressively; it also shows them how to comnit aggressive acts" (p. 7).

In addition, Skornia (1978) related heavy viewing with juvenile crime: "The fact that youth readily learn what television teaches is 
substantiated in a $1200 \%$ increase in juvenile crime during the last $20-$ year America's TV Age" ( $p$. 7) A child watching television for even a short period of time will learn methods of murder.

Freud (1905) in Jokes and Their Relation to the Unconscious interpreted aggression or hostile humor as

a veiled form of attack which satisfies an aggressive motive of its author. Cartoons, jokes, and anecdotes which derogate an objective or emphasize themes of its destruction or suffering all fall under this rubric. When an audience laughs at or enjoys aggressive humor it has accepted the humorist's implicit invitation to join in the assault. (p. 203)

Children imitate aggressive acts regardless of whether the figure is live or on $f i 1 m$. In early research on modeling, researchers like Bandura, Ross, and Ross (1963) concluded that "Subjects who viewed the aggressive human and cartoons models on film, exhibited nearly twice as much aggression as did subjects in the control group who did not see aggressive film content" (p. 11).

Gerbner (1972) found that "Cartoons have consistently exceeded al1 other categories of programs including action-type in the number of violent episodes." Another report found that cartoons have three times the average rate of violence. According to Sue Jarrell (1982), the chance of a cartoon character being attacked is 800 times higher than in real life.

Dr. Jesse Steinfeld (1975), the Surgeon Genera1, reported to the United States Senate Committee that "while the committee report [Surgeon General's Scientific Advisory Committee] is carefully phrased and qualified in language acceptable to social scientists, it is clear to me that the casual relationship between televised violence and 
antisocial behavior is sufficient to warrant appropriate and immediate, remedial action" (pp. 221-223).

At school the same pattern of behavior is followed by the children who are heavy viewers of television. Several field studies have been conducted in which children received heavy doses of actual cartoon violence and then their assaultive behavior toward peers was observed in classroom or play situations. One such study was reported by Steuer, Applefield, and Smith (1971). Five pairs of children were systematically observed in experimental rooms to gather baseline data on frequency of interpersonal assaultiveness. One child in each pair was then exposed to 50 minutes of film violence over a 5-day period while the partner viewed a non-aggressive film. Three of the five children who viewed the aggressive films exhibited considerable increases in physical assaultiveness toward their peer partners. Hapkiewicz and Stone (1974) pointed out, "It is well known that short exposure to violent interactions among real-life characters will produce disinhibition effects" (pp. 47-58).

Another study that investigated the results of violent cartoons was conducted by Ellis and Sakyra (1972). Although the children were only subjected to 5 minutes of violent cartoons they exhibited significantly more aggression toward their classmates than those who viewed either a neutral film or participated in a discussion group.

A more exhaustive field study was conducted by Friedrich and Stein (1973). Nursery-school children were exposed to cartoon versions of "Batman" and "Superman" over a 4-week period and their interactions with peers were systematically observed and recorded. Children who viewed the violent cartoons, were then compared to children who had 
watched prosocial programs ("Mister Roger's Neighborhood") or neutral films. Results revealed that children who were initially above average in aggressiveness were more verbally and physically assaultive after viewing the violent cartoons than those who had seen prosocial or neutral films.

Siegel (1956) found no significant cartoon effects of aggression toward another child, toys, or self during free play. Two other studies which used physical aggression toward a peer-partner also failed to find an increase in aggression after viewing violent cartoons. Hapkiewicz and Roden (1971) used the same cartoon character (a)though not the same $f i l m$ ) as Siegel (1956). In two experiments Lovaas (1961) found that violent cartoons did not increase children's play with aggressive toys above operant level. However, in a third experiment children selected to play with an aggressive toy more frequently than a non-aggressive toy after viewing the violent cartoon.

\section{Summary}

Most studies suggest that children tend to display more aggressive behavior as a result of heavy viewing of cartoons. Although efforts have been made to lessen the number of programs that feature violence these endeavors have not been successful. Cartoons show violence in a far greater degree than in real life.

\section{Auditory vs. Visual Effects on Television}

Although television is thought to play an important role in promoting cognitive and social development (Ball \& Bogatz, 1970; Collings, 1978), relatively little is known about the manner in which young children process information conveyed via this type of mass 
communication. Several years ago, Ward and Wackman (1973) outlined a model of information processing for televised events. In this model, they posited age differences in the type of features children selected for processing while attending to television. Specifically, they suggested that preschool (or preoperational) children focus their attention on visual features of televised presentations and attend less closely to other characteristics (e.g., semantic or auditory features). Such differential attention is assumed to evoke better comprehension/retention of visual than auditory or other types of information.

Research conducted to assess processing of static pictorial information has suggested that young children often ignore auditory input (e.g., experimenter labeling of pictures) and rely on visual characteristics of stimuli for retention (Conrad, 1972; Hays \& Schulze, 1977). It has also been demonstrated that children's visual attention to mass media events (i.e., fixation on the screen) varies as a function of a program's content and noncontent features (Anderson \& Levin, 1976; Susman, 1978). Moreover, Hale, Miller, and Stevenson (1968) reported that grade-school children show more accurate retention of a movie's visual than verbal content, although the effect may have been due to differences in presentation duration for the two types of material.

Zuckerman, Ziegler, and Stevenson (1978) reported that gradeschool children were more accurate in recognizing visual than auditory segments from commercials. Although this finding is consistent with their hypothesis, it does not provide strong support for the notion 
that preschoolers generally remember more of what they see than what they hear on television.

First, correct performance was at chance in this study and the visual-superiority effect varied with the semantic content of the stimuli. Second, the predominant material used by Zuckerman et al. (1978) was cereal commercials, which may predispose different types of information processing than those normally occurring while viewing popular television shows.

It does seem plausible, however, that preschoolers might even look and not listen while attending to television. Given the advanced vocabulary and sophisticated humor comprising the sound tracks of many shows that are popular with children, preschoolers may be unable to understand many of the auditory characteristics. In fact, preschoolers' comprehension of television shows, as well as their integration of successive events within a show, has been described by Collins (1978) as highly fragmented. One possible source of this fragmentation may stem from young children's reliance on visual rather than auditory features for processing televised information.

Hayes and Birnbarn (1980) performed three experiments to assess the degree to which preschool children and adults remember information from the video versus audio portions of television shows. Two types of cartoons were generated to examine this issue: a composite cartoon in which the sound track was inappropriate for the events portrayed visualiy and a normal cartoon in which certain events were presented only visually, only aurally, or both visually and aurally.

The results showed that for children, retention of events portrayed visually was consistently higher than retention of auditory 
information, whereas adults showed comparable retention of the two types of events. For the composite cartoons, very few children realized that a marked discrepancy existed in the visual versus auditory story lines. The results suggested that preschoolers tend to ignore large parts of the audio portions of certain television programs and pay greater attention to the visual aspects of those presentations.

\section{Summary}

These research studies have similar conclusions. Children pay more attention to the visual effects of television than the auditory. Children's retention of information is also greater when it is seen rather than when it is heard.

\section{Desensitization and Television}

As Harry Skornia, vice-president of the National Association for Better Broadcasting, has warned,

If I were to attempt to destroy a Nation internally, I would brainwash the nation into accepting violence. I would educate masses to hate and to kill and burn and destroy. I would condition people to tolerate violence as an acceptable type of behavior and condone its use as the most effective way to solve problems. I would provide specific lessons in the use of guns and knives and show how cars can be used as instruments of death. I would present this information entertainingly--in the form of television. (p. 13)

As one 11-year-old Denver child said, "You see so much violence that it's meaningless. If I saw someone really get killed, it wouldn't be a big deal. I guess I'm turning into a hard rock." Children become desensitized to violence because of its alarming frequency (Jarre11, $1980)$ 
Disinhibition effects are more important in studies of cartoon violence because it is often impossible for the viewer to model the novel response displayed by imaginary situations. In other words, youth and adults may learn that violent behavior or aggressive tactics are appropriate under many circumstances. Some who spend significant amounts of time watching programs with high action, violence, and antisocial behavior may begin to assume that they are reflective of a similar rate of such occurrences in the world. Such viewers would learn gradually to accept a higher level of violence or antisocial behavior as being normal.

A number of studies with children (e.g., Cline, Croft, \& Courrier, 1974) have provided data which suggest that the development of this frame of mind or attitude may result in a greater tolerance of violence when it occurs, a decrease of empathy toward others in distress, or an increase in apathy relative to the helping of victims.

\section{Prosocial Behavior and Television}

Television has been demonstrated to be not only a negative agent in the child's socialization, but also a positive prosocial agent (McCoy, 1981). McCoy found that older children, 8 to 10 years, were able to recall most of the prosocial content of "Fat Albert" and the "Cosby Kids," but 5- and 6-year-olds could not unless they had help in understanding the program.

Hoffman (1970) reported that exposure to models can increase children's altruism or generosity to others and can promote the setting of high standards for self-reward. Also, children tend to become more altruistic themselves when watching prosocial TV. 
Stein and Friedrich (1972) used naturalistic observation to assess the effects of prosocial media on preschool children. From observed behavior these children were classified as "aggressive," "prosocial," or "self controlled." The children were randomly assigned to three groups to view different types of programs over a four-week period. The first group was shown aggressive cartoons such as "Superman" and "Batman." The second group was shown neutral films of children on a farm. The third group was shown "Mr. Rogers Neighborhood," a program which demonstrated cooperation. The study showed that the programs did have a significant effect upon the future aggressive or prosocial behavior of the children.

A study by Miller (1983) tested the verbal and non-verbal response patterns in the programs offered to a preschool audience between cartoon animal models and real human models. The cartoon animal models offered in the analysis demonstrated that cartoon programming has a greater impact and flexibility in proving both prosocial and punitive models of behavior. When cartoon animal features such as "Korg," "Pink Panther," and "Top Cat" were compared with human live action educational presentations, including "Mr. Rogers," "Sesame Street," and "Electric Company," statistically significant differences were realized in verbal response styles in favor of the educational, human, live programs. Likewise, when these same programs were compared on non-verbal response styles, human live-action educational features again demonstrated more favorable models than did cartoon animal features presented for television viewing.

In assessing the effects of both prosocial and aggressive response styles in the form of verbal and non-verbal response patterns, 
it would appear that television can effectively increase behavior patterns of both types. It can also encourage forms of interpersonal effectiveness by discouraging the use of more aggressive role models in cartion animal features and enhancing interpersonally oriented role models in both cartoons and human live action features.

The socially valued, behavior-oriented programs offered models showing greater control by persisting in tasks, obeying rules, and tolerating delays that children are often called upon to deal with in everyday life situations. Furthermore, emphas is on perceptual motor functioning and materials dealing with social behavior within the context of peer relationships was considerably more effective in both non-verbal and verbal response styles in the educational category of television programs than in the commercially produced cartoon features.

\section{Summary}

Studies indicate that television can have an effect upon prosocial behavior. This seems to be the case with older children above the age of 8 to 10 years old rather than the younger age group. Children that are exposed to aggressive type programming show more aggressive behavior. Those that view prosocial programs are more Tikely to demonstrate more prosocial attitudes.

\section{Reality and Fantasy}

By age 18, the average child has watched 17,000 hours of television. People dream, daydream, engage in reverie, read novels, attend the theatre and movies, and view a lot of television. The world of make-believe and imaginative play is central in the lives of 
children. Adults may also participate in dramatic play and perhaps construct stories as an avocation or vocation.

In assessing the impact of television on the child, an important concern is when and how children develop their perception of what is real versus what is pretense on television. Piaget (1966) suggested that children's perception of reality passes through distinct stages as they gradually learn to separate themselves from the surrounding world and discriminate between what is real from what is not in the adult scene.

Results from studies of children's perception of reality in various types of situations, such as playing with a live animal (DeVries, 1969; Kohlberg, 1968), listening to stories (Lottan, 1967), looking at pictures (Taylor \& Howe11, 1973), and viewing television (Brown, Skeen, \& 0sborn, 1979; Noble, 1966) have generally indicated that a child's ability to distinguish between reality and fantasy increases with chronological age.

In addition to age, the content and type of the perceptual situation (story, picture, cartoon, or live actors on television) appear to be important in determining how children perceive reality versus pretend. For example, children who realized that cartoon programs were "pretend" thought that fantasy programs which had live actors were real (Lyle \& Hoffman, 1972).

Because preschool children are dependent upon immediate perception and lack the capacity for abstract reasoning, they are strongly influenced by appearance. When viewing television they find it difficult, if not impossible, to understand that actors play roles, cartoon characters are not alive, and scenes are artificial copies of 
real situations. Instead, they think that all events on television are real (Stevenson, 1972). Stein (1971) contended that children have a particularly hard time perceiving what is real versus pretend on television because it is such a realistic medium in which real and fictional events are presented in similar ways.

Studies by Baron (1980) and Hawkins (1977) reported agerelated increases in the expression of causal relationships between the reality of the image and the production techniques employed to create the reality. Young children (ages 4-5) frequently refer to the "magic" and the "tricks" of television while older children (ages 12-13) are apparently better able to differentiate reality versus fantasy. Baron found that various television concepts tend to be understood at different ages. For instance, children 7- or 8-yearsold exhibited conceptions of cartoon reality, the reality of stunts, (i.e., is a person who is shot really dead), the roles of actors, and the use of scripts.

Concepts related to special effects, program scheduling, (i.e., who decides what programs are shown), and transmission of television signals were later in developing, with limited understanding emerging around age 12 or 13 years. Morever, these concepts may not be fully understood until adulthood. The findings suggest that qualitative differences exist in the way younger and older children perceive the reality of television content.

A personality variable which has been found to be related to the same adaptive behavior is that of locus of control of reinforcement (Rotter, 1954). Locus of control of reinforcement (LOC) is conceptualized as an individual's generalized expectancies regarding 
reinforcement in the environment. A person who believes that reinforcement is determined primarily by chance or luck is said to have an "external" LOC orientation, while an "internal" individual is more likely to believe that reinforcement is a consequence of personal abilities or efforts. Saturday morning cartoons suggest that reinforcement is frequently a function of fate, luck, or supernatural powers--essentially an external locus of control orientation.

Boblick and Nowicki (1984) found that younger viewers may come to expect that problems are solved by calling for a superhero, by drinking a magic potion, or by the rising and setting of the moon on Saturday morning cartoons. Feshbach (1976) pointed out that the fantasy experience provided by some television programs with aggressive content can control or reduce aggressive acting-out behavior because the fantasy provides a substitute for aggression toward the actual target, because it provides an opportunity for the expression of anger, because it functions as a cognitive control, because it is satisfying and enjoyable, and because it may facilitate new insights and cognitive reorganization.

\section{Summary}

Preschoolers have a difficult time in distinguishing between reality and fantasy because of their cognitive skills. It is difficult for them to understand that the roles played by cartoon characters and actors are artificial copies of real situations. Research indicates that a child's ability to distinguish between reality and fantasy increases as the child grows older. 


\section{Later-in-Life Effects of Television}

The increased interpersonal and object-oriented aggressiveness that some studies have reported, though less than immediately violent, does have implications for future behaviors. Data now exist showing that certain aggressive or deviant acts in early childhood or early adolescence are related to later-in-life antisocial behavior and that the more aggressive school boys tend to become more aggressive and antisocial youths and young adults.

Several studies also link the heavy viewing of televised violent programs to violent and antisocial behaviors. Two studies support this point. In a noteworthy study by Belson (1978) 1,650 London teenage boys were evaluated through interview data for violent behavior attitudes, background, and exposure to television violence. They were divided into two groups based on the extent of violence viewing, equated on certain variables, and then compared. Belson reported strong evidence that heavy television viewing increased the degree to which boys engaged in serious violent behaviors such as burglary, property destruction, infliction of personal injuries, attempted rape.

The second study was a longitudinal one by Eron (1972) and his colleagues. Subjects, first seen in 1960, included the entire third grade of a New York county. They were seen in the classroom for a series of tests and questionnaires. Personal interviews were also conducted with parents to determine learning conditions in the home which would relate to aggression of children in school as rated by peers. In 1970 the subjects, now about 19 years old, were interviewed again and retested. The best single predictor of aggressiveness at 19 
years of age turned out to be the violence on television programs the subjects preferred when they were 8 years old. This finding was a major basis for the conclusion in 1972 by the Surgeon General's Scientific Committee that televised violence seemed casually linked to children's aggressiveness (Eron, Lefkowitz, \& Huesmann, 1977).

A third phase of Eron's study has now Deen completed. Over 300 of the subjects were reinterviewed 10 years later in 1980 at age 30. Measures of psychopathology as well as interpersonal skills competence and television habits were collected. Hospital and criminal justice data were gathered. Spouses and children of the subjects also were interviewed. Or. Eron's analyses indicated that the peer-rated aggressiveness or acted-out behaviors at age 8 do predict over 22 years to the number and seriousness of crime arrests, number of traffic accidents and moving violations, conviction for driving while impaired, and the extent of spouse abuse.

The data also showed that the violence of preferred television programs at age 8 continued to be an important variable, being correlated significantly with subject's self-rating of aggression, alcohol use, and with several of the above public record violations (Eron \& Huesmann, 1984).

Singer and Singer (1980) in two short-term longitudinal studies followed middle-class and lower-socioeconomic class 3- and 4year-olds, assessing both their television viewing and behavior four different times. The researchers concluded in both studies that watching violence on television was a cause of heightened aggressiveness. Longitudinal follow-ups of these children continued to show the same relationship 3 to 4 years later. 
McCarthy and colleagues in 1975 concluded the same after studying 7325 -year-old children. Several kinds of aggressive behaviors, including conflict with parents, fighting, and delinquency proved positively associated with degrees of aggressive television viewing.

Heusmann, Lagerspetz, and Eron (1975) collected data on 758 first and third graders for each of 3 years through an over lapping longitudinal design which then provided data for grades 2 to 5 . Similar data were collected on 220 children in Finland. Analyses revealed that violence viewing was related to concurrent aggression and significant predicted aggression levels several years later for boys in both countries and for girls in the United States. Sophisticated analyses did not reveal a consistent effect for all crimes but did show that the introduction of television conclusively increased larcenies and less definitively increased auto thefts.

In a Canadian study reported by Williams (1978), aggressive behavior of primary-school children in a small community was assessed before and after television was introduced. These data were compared with that for children of two other towns who already had access to television. Increases in both verbal and physical aggression after television was introduced were significantly greater here than in the two comparison communities.

A caveat is in order as this literature review is concluded. The research evidence is based on studies of groups and does not permit one at this time to make a definitive prediction that a particular individual is violence prone or anti-social on the basis of heavy viewing of televised violence alone. Behavior is complex and 
29

multidetermined. Television influences are important but there are other potential influences at work. Whether a particular heavy television viewer will act aggressively or be antisocial also depends on other aspects of $h$ is background and the existence of environmental instigators or restraints on his acting out. The extensive research has demonstrated that television is an extreme agent of socialization that can inculcate undesirable social lessons (Poulos, Harvey, \& Liebert, 1976). 


\section{CHAPTER III}

METHODOLOGY

\section{Research Design}

This was a cross-sectional study in which two groups were compared to find if a significant difference existed between religiously oriented children and non-religiously oriented children in their pattern of television viewing in the areas of content and time and to learn if this pattern continued or changed from 3 rd to 12 th grades.

\section{Population and Sample}

The sample of this study was comprised of students from both a private system and a public-school system in southwestern ilichigan. The sample was comprised of 3rd, 6th, 9th, and 12th graders which included 183 students from the private schools and 195 from the public schools for the second semester of the 1986-87 school year. Two groups were randomly selected from each grade (i.e., two 3rd grades, two 6th grades, two 9th grades, and two 12th grades) in each of the two school systems. Thịs resulted in four groups from each grade level.

\section{Instrumentation}

The questionnaire distributed among the students was designed by the researcher and consisted of 12 questions intended to measure the patterns of television viewing. The first four questions collected 
personal data about the student; age, sex, grade, and private or public school attendance. Questions 5 through 8 described television viewing during school days and weekends, parental involvement, and hours per week watching home videos. Questions 9 through 11 dealt with the extent of religious activities and question 12 measured the preference of the students toward crime-action or educational-altruistic programs. The instrument is in appendix A.

\section{Procedures}

The principals for the private religiously affiliated school system and the superintendent for the public-school system were contacted to request permission to conduct the study. Letters were sent to the parents of the children in grades $3,6,9$, and 12 who were to participate in the study. The private-school parents indicated a yes or no answer to participate in the research. The public-school parents were requested to inform the researcher if they did not wish their children to participate in the research due to its religious nature.

A pilot study was done in the private school to determine if the questions would be clearly understood by the students. The teachers distributed the questionnaires to the students in grades 6,9 , and 12 and collected them. Third graders, because of their cognitive and reading-skill levels, were read the questions by the researcher but allowed to give their individual responses. All the groups were randomly divided into two classes for each grade level in both private and public schools. 
Returns were received from 378 students and all questionnaires were used in the analysis. All data were analyzed anonymously by computer.

\section{Hypotheses}

The following hypotheses were tested:

1. There is no significant difference between religiously oriented and non-religiously oriented children in hours per day viewing television.

2. There is no significant difference between religiously oriented and non-religiously oriented children in the number of hours of television viewing at different grade levels.

3. There is no significant difference between religiously oriented and non-religiously oriented children in the number of hours of viewing crime-action programs on television.

4. There is no significant difference between religiously oriented and non-religiously oriented children in the number of hours weekly viewing crime-action television programs at different grade levels.

5. There is no significant difference between religiously oriented and non-religiously oriented children in the number of hours of viewing educational-altruistic programs on television.

6. There is no significant difference between religiously oriented and non-religiously oriented children in the grade levels in the number of hours of viewing educational-altruistic programs on television. 


\section{Dependent Variable}

The extent of religious orientation is defined and based on the following characteristics:

a) have daily family worship

b) spend some time personally reading the Bible or engaging in religious activities

c) go to church regularly.

\section{Independent Variable}

The independent variables are:

a) time (hours of TV watching per day)

b) content (crime-action/educational-altruistic)

\section{Statistical Analys is}

All hypotheses, that is $1,2,3,4,5$, and 6 , were tested by analysis of variance. Analysis of Variance test statistical significance for experiments involving one or more factors and two or more levels on each factor.

\section{Sumary}

This chapter presented the research methodology which included the description of the population and sample, the instrument used in the study the procedures, and the null hypotheses. Mention was also made of the statistical method and analysis. 


\section{CHAPTER IV}

\section{RESULTS}

This chapter presents the findings of the study and follows a two-sector format. First, the hypotheses are tested; second, the hypothesized relationships are summarized, described, and formally accepted or rejected.

\section{Profile of the Subjects}

The study sought to find whether significant differences existed in the children's religious orientation and their patterns of television viewing habits. Subjects were 3 rd, 6th, 9 th, and 12 th graders, which included 183 students from a private church affiliatedschool system and 195 students from a public-school system in southwestern Michigan for the second semester of the 1986-87 school year.

An instrument developed by the researcher identified the extent of religious activities and habits of television viewing. The television viewing habits of these two groups were determined by classifying the students' program orientation and preferences, and by number of viewing hours.

of 378 respondents, 181 were identified as religiously oriented children and 197 as non-religiously oriented children. of these, 188 preferred crime-action television programs, 76 preferred educational-altruistic television programs, 81 preferred both crime- 
action and educational-altruistic television programs, while 38 had no preference.

\section{Description of Hypothesized Relationships}

Each of the hypotheses cited in Chapter 3 was examined individually. In order to facilitate retaining or rejecting the hypotheses, they were stated in the nul1 form according to its statistical criterion of 00.05 .

Hypotheses 1 and 2

Hypothes is 1

There is no significant difference between religiously oriented and non-religiously oriented children in hours per day viewing television.

\section{Hypothes is 2}

There is no significant difference between religiously oriented and non-religiously oriented children in the number of hours of television viewing at different grade levels.

Table 1 contains the mean daily hours of television viewing by children of each orientation at each grade leve1. Some apparent differences appear in the table. The religiously oriented children watch less television per day than the non-religiously oriented children. This pattern was consistent from the 3rd to the 12 th grades. Analys is of Variance was used to test whether these differences are statistically significant for hypotheses 1 and 2 . Table 2 shows the analysis of variance. 
TABLE 1

HOURS OF TELEVISION WATCHING PER DAY

\begin{tabular}{lccccc}
\hline & \multicolumn{5}{c}{ Grades } \\
\hline Groups & 3rd & 6 th & 9 th & 12th & Average \\
\hline $\begin{array}{l}\text { Religiously } \\
\text { oriented }\end{array}$ & 2.22 & 2.19 & 2.00 & 2.24 & 2.15 \\
$\begin{array}{l}\text { Non-religious ly } \\
\text { oriented }\end{array}$ & 3.10 & 3.50 & 3.60 & 4.00 & 3.35 \\
\hline & 2.66 & 2.84 & 2.80 & 3.12 & \\
\hline
\end{tabular}

TABLE 2

ANALYSIS OF VARIANCE-ORIENTATION BY GRADE

NUMBER OF HOURS OF TELEVISION VIEWING

\begin{tabular}{lrccrc}
\hline & \multicolumn{1}{c}{$\begin{array}{l}\text { Sum of } \\
\text { Squares }\end{array}$} & $\begin{array}{c}\text { Degree } \\
\text { of Freedom }\end{array}$ & $\begin{array}{c}\text { Mean } \\
\text { Square }\end{array}$ & $F$ & $\begin{array}{c}\text { Tail } \\
\text { Probability }\end{array}$ \\
\hline Orientation & 95.38299 & 1 & 95.38299 & 23.32 & $<0.00005$ \\
Grade level & 3.04407 & 3 & 1.01469 & 0.25 & 0.8625 \\
Interaction & 10.33104 & 3 & 3.44368 & 0.84 & 0.4716 \\
& 1484.77549 & 363 & & & \\
\hline
\end{tabular}


Table 2 shows that there was no significant interaction between orientation and grade level. There was no significant difference between grade levels. For religious orientation, the $F$ ratio of 23.32 had a probability of $<.00005$. There is a significant effect for religious orientation. The religiously oriented children watch significantly less television than the non-religiously oriented children. Hence, Hypothesis 1 is rejected and Hypothes is 2 is retained.

Hypotheses 3 and 4

Hypothes is 3

There is no significant difference between religiously oriented and non-religiously oriented children in the number of hours of viewing crime-action programs on television.

Hypothes is 4

There is no significant difference between religiously oriented and non-religiously oriented children in the number of hours weekly viewing crime-action television programs at different grade levels.

Table 3 shows the number of hours of crime-action television programs watched by each group at each grade level. In both the religiously oriented and non-religiously oriented groups, the 3rd graders were the heaviest viewers of crime-action television programs. The average number of hours decreases as the grade level increases.

Table 4 shows the Analysis of Variance to test the hypotheses 3 and 4. Table 4 shows that there is no significant interaction between religious orientation and grade level. Also, there is no significant difference between religiously oriented children and non-religiously 
oriented children in numbers of hours of crime-action television watching. Hence, hypothes is 3 is retained.

There is a significant difference between grade levels. There appears to be a continually decreasing number of hours of crime-action television viewing on the part of children as grade-level increases. Hence, hypothes is 4 is rejected.

\section{Hypotheses 5 and 6}

Hypothes is 5

There is no significant difference between religiously oriented and non-religiously oriented children in the number of hours of viewing educational-altruistic programs on television

\section{Hypothes is 6}

There is no significant difference between religiously oriented and non-religiously oriented children in the grade levels in the number of hours of viewing educational-altruistic programs on television.

Table 5 shows the number of hours of educational-altruistic television programs for each group. There is little difference in the average hours of viewing educational-altruistic programs between the two groups.

Analysis of Variance was used to test whether these differences are statistically significant. Table 6 shows the analys is of variance.

Table 6 shows that there is no significant interaction between orientation and grade level. There is no significant difference between the religiously oriented and non-religiously oriented children. Thus, hypothes is 5 is retained. 
TABLE 3

CRIME-ACTION TELEVISION PREFERENCE

Grades

\begin{tabular}{lccccc}
\hline Groups & 3rd & 6th & 9 th & 12th & Average \\
\hline $\begin{array}{l}\text { Religiously } \\
\text { oriented children }\end{array}$ & 6.38 & 3.75 & 2.53 & 2.17 & 3.70 \\
$\begin{array}{l}\text { Non-religiously } \\
\text { oriented children }\end{array}$ & 6.77 & 4.86 & 3.18 & 2.05 & 4.21 \\
\hline & 6.57 & 4.35 & 3.00 & 2.00 & \\
\hline
\end{tabular}

TABLE 4

ANALYSIS OF VARIANCE-ORIENTATION BY GRADE

CRIME-ACTION TELEVISION HOURS

\begin{tabular}{lccccc}
\hline & \multicolumn{1}{c}{$\begin{array}{l}\text { Sum of } \\
\text { Squares }\end{array}$} & $\begin{array}{c}\text { Degree } \\
\text { of Freedom }\end{array}$ & $\begin{array}{c}\text { Mean } \\
\text { Square }\end{array}$ & $F$ & $\begin{array}{c}\text { Tail } \\
\text { Probability }\end{array}$ \\
\hline Orientation & 19.50210 & 1 & 19.30210 & 1.48 & 0.2246 \\
Grade level & 894.67656 & 3 & 298.22552 & 22.86 & $<0.00005$ \\
Interaction & 12.78046 & 3 & 4.26015 & 0.33 & 0.8061 \\
& 4761.04614 & 365 & & & \\
\hline
\end{tabular}


TABLE 5

EDUCATIONAL-ALTRUISTIC TELEVISION PREFERENCE

\begin{tabular}{llllll}
\hline \multicolumn{6}{c}{ Grades } \\
\hline Groups & 3rd & 6th & 9 th & 12th & Average \\
\hline $\begin{array}{l}\text { Religiously } \\
\text { oriented children }\end{array}$ & 3.47 & 2.47 & 1.51 & 2.58 & 2.50 \\
$\begin{array}{l}\text { Non-religiously } \\
\text { oriented children }\end{array}$ & 3.55 & 2.41 & 1.63 & 1.52 & 2.28 \\
\hline & 3.51 & 2.44 & 1.60 & 1.77 & \\
\hline
\end{tabular}

TABLE 6

ANALYSIS OF VARIANCE-ORIENTATION BY GRADES

EDUCATIONAL-ALTRUISTIC TELEVISION PROGRAMS BY HOURS

\begin{tabular}{lrcrrrr}
\hline & \multicolumn{1}{c}{$\begin{array}{l}\text { Sum of } \\
\text { Squares }\end{array}$} & $\begin{array}{c}\text { Degree } \\
\text { of Freedom }\end{array}$ & $\begin{array}{c}\text { Mean } \\
\text { Square }\end{array}$ & $F$ & $\begin{array}{c}\text { Tail } \\
\text { Probability }\end{array}$ \\
\hline Orientation & 3.98704 & 1 & 3.98704 & 0.79 & 0.3735 \\
Grade level & 185.89240 & 3 & 61.96413 & 12.34 & $<0.00005$ \\
Interaction & 14.02207 & 3 & 4.67402 & 0.93 & 0.4259 \\
& 1832.79403 & 365 & & & \\
\hline
\end{tabular}


There is a significant difference for grade level. Hence, hypothes is 6 is rejected. There is apparently a decreasing number of hours of educational television watching with increase in grade level. Other non-hypothesized relationships generated by the study are reported in tables 1 through 12 of appendix $C$.

\section{Summary}

Chapter 4 has presented the findings of the study and examined each hypothesis. A significant difference was found in the number of hours of television viewing, the number of hours weekly viewing crimeaction, and the preference for educational-altruistic television programs by grade levels between religiously oriented and nonreligiously oriented children. No significant difference was found in the religious orientation and grade level, orientation toward crimeaction television programs, and the number of hours of television viewing between religiously oriented and non-religiously oriented children. 
CHAPTER $V$

SUMMARY, CONCLUSIONS, AND

RECOMMENDATIONS

This chapter is organized into three sections. The first section contains a brief summary of the problem, methods, and findings of the study. The second is a discussion of the results of the study. The conclusions and recommendations are given in the final section.

\section{Summary}

Statement. of the Problem

Apparently no research has been done to investigate the extent of religious activities and the preference of students toward crimeaction or educational-altruistic programs in grades $3,6,9$, and 12 . As a consequence, there is a need for understanding the effects of television upon children, especially in the religious context. The following research questions were the basis of this study:

1. Is there any significant difference between religiously oriented and non-religiously oriented children in hours-per-day viewing television?

2. Is there any significant difference between religiously oriented and non-religiously oriented children in the number of hours of television viewing at different grade levels? 
3. Is there any significant difference between religiously oriented and non-religiously oriented children in the number of hours of viewing crime-action programs on television.

4. Is there any significant difference between religiously oriented and non-religiously oriented children in the number of hours weekly viewing crime-action television programs at different grade Tevels?

5. Is there any significant difference between religiously oriented and non-religiously oriented children in the number of hours of viewing educational-altruistic programs on television?

6. Is there any significant difference between religiously oriented and non-religiously oriented children in the number of hours of viewing educational-altruistic programs on television at different grade leve1s?

\section{Methodology}

A questionnaire was used to assess the relationship between the use of television (content and time) and the religious orientation of the individual based on the following variables: family worship, church attendance, and personal devotion such as Bible reading.

The sample of this study consisted of elementary and high-school students from a private church-affiliated school system and a publicschool system enrolled during the 1986-87 school year in a small southwestern Michigan town. A random sample of 425 subjects was selected for this study. Of these, 378 completed the questionnaires. All data were analyzed anonymously and computer scored. Significance was set at the .05 leve1. 
Results

Hypotheses 1 and 2

As measured by the analys is of variance hypothes is 1 shows there was a significant difference in hours-per-day viewing television. The religiously oriented children watched significantly less television than the non-religiously oriented children. Thus hypothes is 1 was rejected.

Hypothesis 2 showed no significant difference between grade levels in the number of hours-per-day of television viewing. Also, there was no significant interaction between religious orientation and grade level. Hypothes is 2 was retained.

This pattern is consistent from 3 rd to the 12 th grades. There is an increasing pattern of television viewing from 3rd to the 12th grade for non-religiously oriented and religiously oriented children. What does this say about religious orientation and television viewing? Does it mean that parents of religiously oriented children have a religious orientation themselves and are more careful about the amount of time spent viewing television? Perhaps parents of religiously oriented children find other activities for their children to engage in which would divert their children's attention away from television.

\section{Hypotheses 3 and 4}

Using the Analysis of Variance there was no significant difference between religiously oriented and non-religiously oriented children in the preference for crime-action television programs. Both groups watch approximately the same type of crime-action shows on the 
television. Third graders were revealed to be the heaviest viewers of crime-action television programs. Hypothes is 3 was retained.

A significant difference exists between grade levels in the number of hours weekly viewing crime-action television programs for both religiously oriented and non-religiously oriented children. There appears to be a continual decrease in the number of hours of crimeaction television viewing on the part of children as grade level increases. Hypothes is 4 was rejected.

The study seems to reveal that although religiously oriented children watch less television, their preference is for the same type of programs as the non-religiously oriented children. This could be because of lack of parental guidance, restriction, or peer pressure. According to Fontes (1978) peer pressure may influence the types of programs children watch. This may be the case for children of both orientations.

Studies further reveal that parental commentary lessens the possible effects of television viewing (Mattern \& Lindholm, 1984). If this parental commentary is lacking among both groups, there may be increased viewing of crime-action programs.

The study also shows that as grade level increases, the viewing of crime-action is not significantly different between the groups. The pattern is also the same between the groups in that there is a change in preference from crime-action to other types of television programming. It could be that young people become more interested in their physical development and may tend to watch programs featuring other activities such as sports. 
Hypotheses 5 and 6

No significant difference exists in the number of hours of viewing educational-altruistic programs on television between religiously oriented and non-religiously oriented children. Hence, hypothes is 5 is retained. For hypothesis 6 there is a significant difference in grade levels. There is a decreasing number of hours of viewing educational-altruistic television programs both for religiously oriented and non-religiously oriented children with increase of grade level.

It is worth pointing out that there is a significant difference in the preference for crime-action and educational-altruistic television programs as the grade level increases and there is a decrease in the preference for these two types of television content programming as grade level increases. Third graders are the heaviest crime-action and educational-altruistic television viewers.

It is the belief of the researcher that children establish a pattern of television viewing in grades 2 - 5 that continues through adolescence and perhaps until adulthood. Even though adolescents may watch less crime-action or educational-altruistic programs, the influence that these programs have upon the child early in life may influence adult behavior.

Eron and his colleagues (1972) worked in a longitudinal study that included the entire third grade of a New York State county to determine if television viewing had long-term effects upon the children. In 1970 subjects now 19 years old were interviewed and retested. They found that the best single prediction of aggressiveness at 19 years of age turned out to be the violence of the television 
programs the subjects preferred when they were eight years old. Ten years later (1980) the subjects were reinterviowed, at age 30 . They again found that age 8 continued to be an important variable in serious aggressive behavior. The present study shows significant differences as well as non-significant differences between religiously oriented and non-religiously oriented children in television-viewing habits.

\section{Conclusions}

From the examinations of the findings, the following conclusions are drawn:

1. Religiously oriented children watch television fewer number of hours per day than the non-religiously oriented children. Religious orientation does make a difference in the number of hours of television viewing per day.

2. No significant difference is found between religiously oriented and non-religiously oriented children in preference for crimeaction television programs. Regarding the content of television viewing, both groups watch the same type of crime-action programs.

3. A significant difference exists between grade levels in the number of hours of weekly viewing of crime-action television programs for both groups. Non-religiously oriented children watch more hours of crime-action television per week than religiously oriented children at each grade level and as grade level increases.

4. No significant difference exists between religiously oriented and non-religiously oriented children in the number of hours spent viewing educational-altruistic television programs. Both groups showed a similar preference toward this kind of television programming. 
6. There is a significant differenco by grade level in preference for educational-altruistic television programs. There is a decreasing number of hours of educational-altruistic viewed with increase in grade levels. For both groups preferences for crime-action and educational-altruistic television decrease as grade level increases.

\section{Recommendations}

The conclusions of this study suggest recommendations in two categories: The first for practice and the second for further research.

\section{For Practice}

1. A component of education and counseling could be structured into both educational curricula and ecclesiastical orientation regarding the content and time spent on television viewing.

2. Attempts could be made in schools and churches to improve the quality and quantity of television viewing by implementing workshops and seminars presenting the positive and negative effects of television viewing.

3. A greater emphas is could be placed on educational-altruistic orientation among children and adolescents by more careful selection of prosocial films and programs for television which would encourage these young people to implement prosocial principles: in their daily life.

4. Parents could take more time with children by sitting down and explaining the content of the different programs and pointing out the positive and negative aspects of the television programs. 
For Further Research

1. Since this study sampled grades 3 to 12 , it is recommended that it be expanded to include college students.

2. Since the study covered some of the private schools in southwestern Michigan, it is recommended that this study be replicated in other areas of the United States.

3. It is recommended that this study be expanded to other countries.

4. Also, a larger sample could be taken to expand the perspectives of this study.

5. Further study is needed to determine the effects of television--positive or negative--upon the religious orientation of the individual. 
APPENDICES 
APPENDIX A

QUESTIONNAIRE 
Instructions: Read each question carefully, and answer each one of them. Check $(v)$ or circle when asked to.

1. Age 2. $\operatorname{Sex} F / M$

3. Grade: $3 r d$, 6 th, 9 th, 12 th

4. Are you in: Public School Private School

5. a) How many hours per day do you watch television during the school week?

$$
\begin{array}{llllllll}
0 & 1 & 2 & 4 & 5 & 6 & 7 & \text { or more }
\end{array}
$$

On school days, during what time do you usually watch TV?

1) before school; 2) right after school;

3) evening

b) Do you watch TV during the weekend? no yes If yes, when?

1) almost every Saturday morning;

2) almost every Sunday morning;

3) almost every Saturday afternoon or evening;

4) almost every Sunday afternoon or evening;

5) Rarely

6. On non-school days, how many hours of TV do you watch? Circle one, please. Saturday

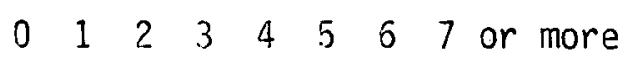
Sunday

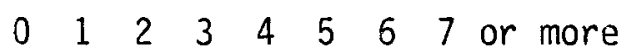

7. When your parents watch TV with you, do they explain what's happening in the program? Check ( $\boldsymbol{r}$ ) one, please.
1) Never;
2) Rarely;
3) Quite Often;
4) Almost Always;

5) Never watch with me.

8. a) How many hours do you spend watching home videos per week at home? circle one.

$$
\begin{array}{llllllllllll}
0 & 1 & 2 & 3 & 4 & 5 & 6 & 7 & 3 & 9 & 10 & \text { or more }
\end{array}
$$

9. How many days do you have family worship at home during the week?
1) $7-5$

2) 4-3;

3) $2-1$

4) 0

10. How often do you gis to church?

1) almost every Sunday;

2) aimost every Saturday;

3) sometimes, but not every week;

4) almost never 
11. How many minutes do you spend each day at home reading the Bible or any other religious activities? Check $\left(r^{r}\right)$ one, please.

1) Less than 10 minutes; 2) 11-19 minutes; 3) 20 minutes or more

b) What types of videos do you generally watch? Check $(x)$ one, please.

1) Family movies;

2) Crime-Action; 3) Cartoons; 4) None

12. What programs do you usually watch on television? Check $(\checkmark)$ as many as apply to you.

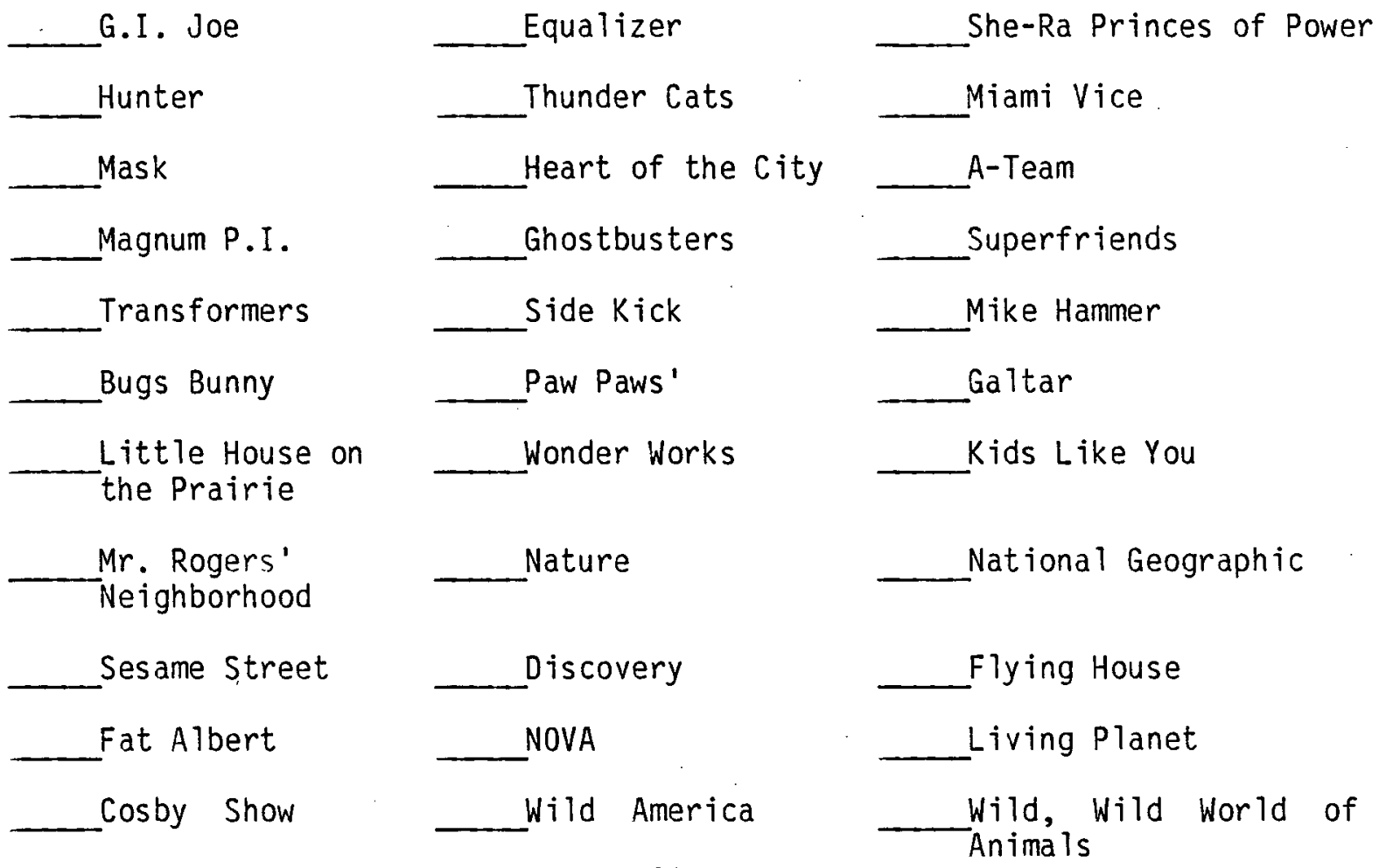

Can you mention some others you usually watch? 
APPENDIX B

LETTERS 


\author{
Andrews University \\ Garland Apartments, F-16 \\ Berrien Springs, Michigan 49103 \\ Apri1 2, 1987
}

\title{
Dear Parents:
}

As part of my graduate studies, permission has been granted to me by Andrews University and by the Superintendent of the Berrien Springs Public Schools to contact the parents of Elementary and High School students here in Berrien Springs.

I am surveying grades three, six, nine and twelve regarding possible effects of television on youngsters with varying levels of religious experiences. The results of this survey will be treated with very strict confidentiality. Your child will not be asked to divulge his/her name. A questionaire will be given to each child in their own room by their own teacher.

The results of this survey will provide valuable information that will be very useful in assisting your child during the foundational years of his or her education. The results of this survey will be made available upon your request by the last week of May, 1987 .

If you do not wish to have your child participate in this study, please sign and return the bottom portion of this letter to school with your child.

Thank you for your consideration and cooperation.

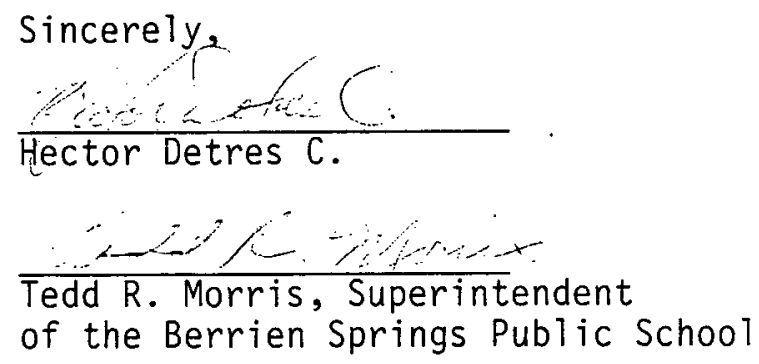

I do not wish to have my child participate in the study related to religion and the effects of television on young viewers. 
APPENDIX C 
TABLE 7

RELIGIOUS ORIENTATION BY GRADES

(NUMBERS NOT AVERAGES)

\begin{tabular}{lcccc}
\hline \multicolumn{5}{c}{ Grades } \\
\hline Schools & 3rd & 6 th & 9 th & 12 th \\
\hline Private school & 25 & 24 & 34 & 11 \\
Public school & 20 & 11 & 3 & 4 \\
\hline & 22.5 & 17.5 & 18.5 & 7.5 \\
\hline
\end{tabular}

TABLE 8

NON-RELIGIOUS ORIENTATION BY GRADES

(NUMBERS NOT AVERAGES)

\begin{tabular}{lcccc}
\hline & \multicolumn{3}{c}{ Grades } & \\
\hline Schools & 3rd & 6 th & 9 th & 12th \\
\hline Private school & 7 & 12 & 44 & 23 \\
Public school & 30 & 32 & 62 & 33 \\
\hline & 18.5 & 22.0 & 53.0 & 28.0 \\
\hline
\end{tabular}


TABLE 9

HOURS OF VIDEO VIEWING PER WEEK

\begin{tabular}{lcccccccc}
\hline \multicolumn{10}{c}{ Hours } \\
\hline Groups & 0 & 1 & 2 & 3 & 4 & 5 & 6 & Last \\
\hline $\begin{array}{l}\text { Religiously } \\
\text { oriented children }\end{array}$ & 40.4 & 22.1 & 12.5 & 7.4 & 7.4 & 2.2 & 2.9 & 5.1 \\
$\begin{array}{l}\text { Non-religiously } \\
\text { oriented children }\end{array}$ & 27.9 & 11.2 & 22.7 & 9.9 & 9.9 & 3.9 & 4.7 & 9.9 \\
\hline & 32.5 & 15.2 & 19.0 & 8.9 & 8.9 & 3.3 & 4.1 & 8.1 \\
\hline
\end{tabular}

TABLE 10

VIDEO-MOVIES PREFERENCE

\begin{tabular}{lcccc}
\hline & & & & \\
\hline & $\begin{array}{l}\text { Family } \\
\text { Movies }\end{array}$ & $\begin{array}{c}\text { Crime- } \\
\text { Action }\end{array}$ & Cartoons & None \\
\hline Groups & 1. & 2. & 3. & 4. \\
\hline $\begin{array}{l}\text { Religiously } \\
\text { oriented children }\end{array}$ & 34.1 & 38.5 & 8.9 & 18.5 \\
$\begin{array}{l}\text { Non-religiously } \\
\text { oriented children }\end{array}$ & 27.5 & 60.7 & 3.5 & 8.3 \\
\hline & 29.9 & 52.5 & 5.5 & 12.1 \\
\hline
\end{tabular}


TABLE 11

PARENTAL INVOLVEMENT IN TELEVISION CONTROL

\begin{tabular}{lccccc}
\hline & Never & Rarely & $\begin{array}{c}\text { Ouite } \\
\text { Often }\end{array}$ & $\begin{array}{c}\text { Almost } \\
\text { Always }\end{array}$ & $\begin{array}{c}\text { Never watch } \\
\text { with me }\end{array}$ \\
\hline Groups & 1. & 2. & 3. & 4. & 5. \\
\hline $\begin{array}{l}\text { Religiously } \\
\text { oriented children }\end{array}$ & 22.2 & 42.2 & 23.7 & 8.1 & 3.7 \\
$\begin{array}{l}\text { Non-religiously } \\
\text { oriented children }\end{array}$ & 40.6 & 38.0 & 11.1 & 3.0 & 7.3 \\
\hline & 33.9 & 39.6 & 15.7 & 4.9 & 6.0 \\
\hline
\end{tabular}

TABLE 12

SAMPLE BY. GRADES AND SCHOOLS

\begin{tabular}{lcccc}
\hline & \multicolumn{5}{c}{} & Grades \\
\hline Schools & 3rd & 6 th & 9 th & 12 th \\
\hline Private school & 33 & 37 & 78 & 35 \\
Public school & 50 & 43 & 64 & 38 \\
\hline Total=378 & 83 & 80 & 142 & 73 \\
\hline
\end{tabular}


APPENDIX D

RAW DATA 


\section{Eolumns_Represent__atata_as__Eollows:}

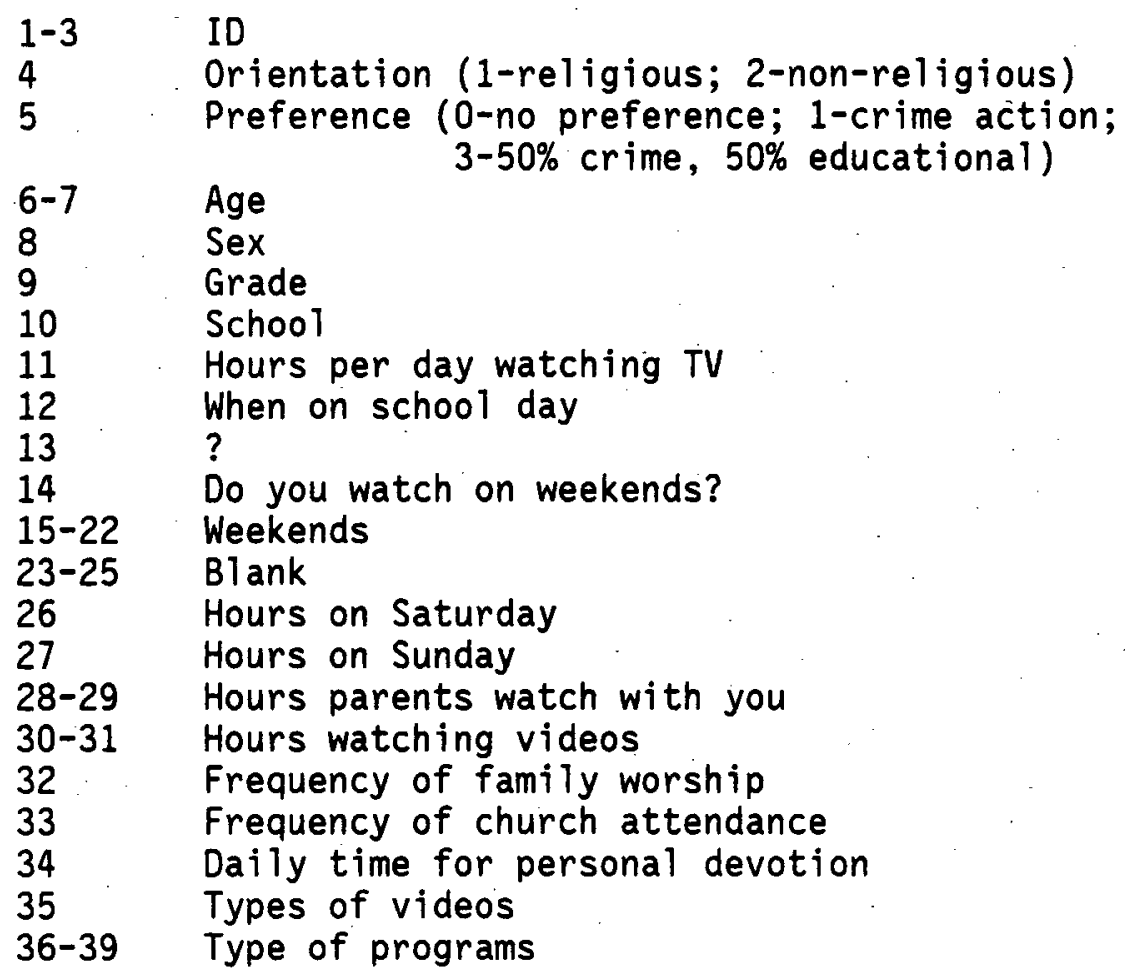


0941115231421122121112 10123142315211 22221 122 1021115231421 22222 1212 10423141313221 22222212 105211413721121221212 1062314131 2221 22222212 10722051313221 222222 12 1082115131721 2221 22222 1092114131721121221212 11021152317221 22221212 1112115231222122221212 11221162314221 222 11112 11321152313221 22222 122 11421162311 221 222222221 1152114231721121111112 1162015131721221 222222 1172115131221222122212 $11821 \quad 1314221$ 22221212 1192315131721 222222221 1202314231711121111112 1212115131622122222212 1 222315131722122222221 1 2323141311221 22221212 1242315131421121212212 1 2522 14131 222 1 2222222 1 1261215131 322 1 2222222 1 1272115231522121121212 1 2823162317221 22212122 1292115231721221222122 1302115231711122121112 13121151317221 222 1 2222 1 उ221 052314221 2222 1222 13323151314221 22221212 13421151313221 22221212 1352114131722121221212 13621152313221 22221112 1372015231511121111112 1382015231121222222221 13922162314221 2222222 1 1402214131322121221212 1412115231721122221212 1422015231122121221221 14321162313221 22221212 1442315131521121221212 14521151313221 2222222 1 1462315231422121112112 1472214231111121211212 1482315231511122211212 1492214131422121 222222 1502114131422121211212
2520012140602 3040244120101 $531064 \quad 1220400$ 3310041120101 7410541120401 110144140101 0210542110103 $051104 \quad 2120301$ $751004 \quad 1120801$ 3220231120601 111004420301 6510331120601 1420141120201 111004420100 7710642121004 310643110000 1320144120402 5520344120601 2020441110101 $771104 \quad 4120909$ 0010044120201 उ22023 1110101 1110041120101 $741024 \quad 4120302$ 1150543110001 2130121330103 7720644121403 5710242120001 $771004 \quad 4120601$ 4710242141304 3310041120201 2030144120200 3310044110302 3310042140601 $541014 \quad 1120201$ 3420242120301 $772024 \quad 4 \quad 0000$ $102104 \quad 1120000$ 2010744120002 421004410001 7711043120401 3250043120000 322024420301 6320443120302 $332024 \quad 4120301$ 5620341120403 $742083 \quad 3120205$ 7520034110706 $32034 \quad 1120103$ $642054 \quad 3120501$ 
1512114231 222 1 222222221 1 522217231522121 222222 1532315231121 2ट221 2222 1542315231322122211212 1552115231 222 1 2อ22 1211 156231531711121221221 1572115131321221221222 1 5822171413211 22222221 15921182413221 22222221 1601218241112222122212 1612318241122122122222

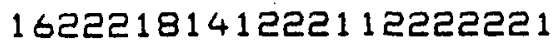
1632118241 222 1 2222 1212 16422171410221 22221 1221 1651318141721121211112 166131841322122122112 1671318141 222 1 222222221 1682118241522122222122 16921181417221 222 11112 1702318141222122222221 1712118241 222 1 22222222 1 172221814172122221 2222 1732118141321 222222221 0742117141222122221212 17522181412221 22222 112 1762118141 2221 22221212 1772118241422121112122 1782318241 2221 221 122222 1792118241322121222212 1802117141 2212222221 221 1812117141722121112122 1822218141422121221212 1832117241122122221212 1842117241522121222212 1852218141 222 11 22222222 1862218241722121211112 1872318241421122122222 1 8822181412221 22221 1 222 1892118141321 2222 1 2222 1902317141222121212221 19123182413121221.11122 1 922218141322121221212 193121841122122221222 1942136241 2221 22222221 1952118141521121111112 1961109212122122221121 19721092120222 2222221 19811091123212221 222 11 1991209112121222121212 200120921 22221 22222221
2222004
3140300
$205024 \quad 410206$
2210241120101
5420241120202
$122044 \quad 1120302$
7310344140101
$332044 \quad 410302$
3220341120203
5530043220200
0220042340005
1220214110201
1110241120001
4410041120200
1010241120001
$752042 \quad 1320404$
2520012340303
1010042220101
ट5022 2120502
3320241120301
2210043120101
$221014 \cdot 4120201$
$771024 \quad 4120002$
222024 4140300
42133120201
1410141120102
2220241110401
5530343120602
221044 4120101
3310043120402
$212004 \quad 1120200$
$771004 \quad 1121202$
4410243120306
$221024 \quad 4120500$
2420244140402
001004440002
$771064 \quad 1120308$
520042130303
320643110004
$41014 \quad 4120400$
420043120402
5510044120101
4410444120203
$202004 \quad 1340004$
$125014 \quad 1120806$
76144120301
2220012120502
0050032130905
242002 2210802
0140112330508
2220012110311 
2011111212112222121121 2022110212721222121112 2031109212521 222121212 2041109212311122121112 2051210112122122122121 2062109212221122121212 2072109212121122121212 2081110232 111 22221212 2091110212421122122222 2102108222321222121212 21111092125121 2221112 2122109212122122112122 21311092120222 ट222222 2142109212521122121212 2151209212122122122212 2161109212122122121112 2171109212122122221212 218110921 2222122121212 21910091120222 2222221 ट20100911202ट2 ट22ट221 2211110212022122121122 222 120811 2321 2221 121212 22312091120222 2121112 2241310212211122121112 2251311212511222121212 256120911202521 2525251 2271310112122112222222 2281112123221222121212 ट2922111222221 12221212 23012121 221 221 22251 ट22 2312111122521121221212 2321112122621122121212 23312121223221 22222221 23412121 2202221 2222222 235101222202221 2252252

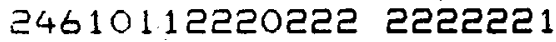
23720 2 2251225e252 2381112122221122121112 2392111122321122121212 ट402212121 ट221 22221212 24112121222221 22222212 24222121221 221 1 222222221 2442311122121222221212 245131 32223 322 1 2222 1 22 1 24611122221211221 22122 2471112222122122121112 248131 22222221 1 222 1 ट22222 249111 2222322122121212 250111222222 11 22221112

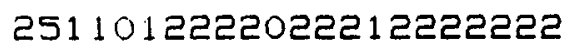

1220012130602 6710042111403 1420032231405 0420012121407 4340112310406 3320042340201

310032110501 1120611311005 5730012210901 7430132111708 $272101 \quad 2310806$ 2320133130100 1.12240201 6420732110201 0220022330204 252011 己 11001 1020122330301 4630112120801 0010012340000 0010032340000 5410312221304 2420012240207

3320112310609 3410712310911 5430112110302 0010012340005 0130012310706 - 2042 2220401 2220242120001 2030232210001 5450042120301 410422310800 430222310608 0010012340003 0010022240000 0010012310000 $200 \quad 2110000$ 4520242320802 2310232110201 3220442110001 0230012240001 $012032 \quad 2120301$ 521024 2120202 220242220403 0320012310503 0620412221304 350012140303 0430022311209 3310012120804 000012240000 
टร21212222121122121112 2531212 22025212525252 254221 1 2222322 1 2222 1212 2551113222311122121212 2561113222ट22122122212 257121 2222221122121112 2582112222521112222221 2591111222525122222a12 260231322 222 2222222 26113122223221 22221112 26213112221221 22221112

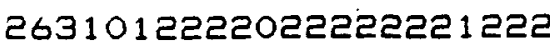
264211 2222221122222112 26512162320221 22221212 26611162322221 22221 1221 26711 122122221112 26812 132022225211222 269201513202251 2ट22222 2701115132421222122112 27111152321 221 22222221 27220152120222 ट222222 27311 232121222222222 27621151322221 25222212 2772114132222121221212 27922 162322221 2222 1222 28022 141321 221 1 2222221 28121151 32222121211222 2821215132122122222212 28321151325221 222211112 28421141325211 22221212 28521141323221 22221212 28622151 327221 22221212 28713162321221 22121222 28823152322221 22121211 2911216232022222221211 29322151 321 221 22222221 29520151320222 ट222222 29623141 320221 2222222 1 2972115212711121111122 2982316211711121212222 2991315 32022122221212 30121151322221 2222 1112 3032315132321121211222 304201521 202221 2222222 उ०5221 6232222 1 222ट 1 ट22 00111101112211212 O0211091111221221 00321091114221212 00421092110212212 o०521101115212211
1320012240105 $005003 \quad 2210001$

1330022120105 43013 2220501 0320112220504 2520112220305 220242121001 0230032240400 $2 \quad 2110403$

650422220303 4320232310202 0030312110000 150042120401 2240012320001 3130642120301 4630112120804 3030312310002 005003 ᄅ 0000 372103 2220502 222011 2220501 $00 \quad 0842110000$ 2110112120000 2210432120301 5510334120802 2020242110001 20042120001

710932120602 223013 2210001 6610122121604 6610014120802 5510342120401 $212024 \quad 2120001$ 1320112120100 4410332120001 3340012310001 1020132120001 00003 2 0000 0150042120001 7711041121815 7041041121815 2240032210201 3410442120500 421032120604 $00074 \quad 2120000$ 2 $3024 \quad 2120001$ 1 ट22 202 21110302 $2210403 \quad 12210502$ 212420234110301 $1217 \quad 108 \quad 34111305$ 111740133130704 
00621101112111221 00711091114121211 OOB11082223212212 00921101117111211 01011102115111211 01111092115212221 01211092116111211 01321092114111212 014212116111211 01511092111211212 01611091111221212 01711082113111211 0181308111421 2221 01921102111221212 02021091112212211 02120101113221212 DE2 1091212111212 02321092111221212 02421102115111111 02521091113111222 02623102110221212 02713091112221212 02811 $114122 \quad 21$ 02921102115211211 0302109111321221 03121102112221212 03221092112121225 03323092113211222 03422092113211211 03522091111221212 03621081113121221 03713091111221222 03821091112121221 03921091116112212 04011082111212221 04111082111221222 04221101113211222 04323102115212212 04423092111211122 04511101116111221 04611091113121212 0472110211321122 0481108211 2221212 04911102111212221 05021091116112221 O5111131213211222 ดร221121215221211 05321121210111111 05423121212211212 05521101217211212
2220 $200 \quad 12340904$
121230014320801
222430011120301
112720934120902
$1125400 \quad 11131201$
112520122310500
122320112121205
$1227 \quad 210 \quad 33121002$
222750033110603
2227 20011330802
211230111210501
$1126 \quad 203 \quad 11130604$
$2120 \quad 300 \quad 12330807$
$2213510 \quad 34120703$
222320134130703
221330033120602
1 222 $100 \quad 33330402$
2211 $108 \quad 34120500$
221740233131307
122420431110401
2222 50334110706
2223 10311330302
2223 $100 \quad 12340601$
1122234120602
ट22 3110602
2212 20233121506
$2213203 \quad 34120100$
$1225300 \quad 34110706$
$1126 \quad 106 \quad 34110304$
212430321110102
121230334130703
221120112210304
121330423211409
$112 \quad 310 \quad 31110501$
$2120303 \quad 12320501$
$1124 \quad 310 \quad 11220801$
2212 10133220300
$1227400 \quad 34120808$
2220 20231110101
2125 204 22320902
2226 $400 \quad 11341003$
$1227 \quad 10434121006$
222330531320802
$2120 \quad 303 \quad 12321406$
212630422110706
$2120300 \quad 22220501$
$1127 \quad 410 \quad 32110401$
112030631110301
122320031110202
112420531110601 
05612111113222222 05722121212211212 05823121113211212 05923121214211212 06021122215121211 O6121122217211211 06211122216221222 06313111212211 222 0642112221 222 1222 0652211221 2221222 0662112 215211212 O6722111213221222 06822121212211212 069211 22217212212 070211 22213221212 071211 22217111211 072231 22213211221 073231 222 17121212 07421122213212222 07513131213221 222 07622121212221212 077211 22214221212 07821122215121222 07913111215211222 08023132212221222 08111121212212221 ०8212121214221222 08311111212211212 084211 32213212222 08523141215221221 .08621111214221222 O8723111213221222 08813121214221222 08911132223221212 0902312221 221 1222 09121121214211222 09221122227212212 093211 22211221222 0952115 311221222 09621151312211222 09722151313221212 09821162314221211 09921152313111222 1002215131 222 1222 10311152313121222 27421142324212222 2752114232721 2221 27823161321221122 28711151322221222 28921172327221 222
$2120 \quad 300 \quad 12340204$
2223 50433120002
$1227 \quad 10434110202$
$1224304 \quad 34110604$
$1127 \quad 106 \quad 21221104$
$1127 \quad 110 \quad 33120501$
212730212220402
112120421210101
212030131120303
2212 30021140205
2226 10431220601
122330134110205
2122 $100 \quad 33110104$
122730433121101
212320534121104
$1125205 \quad 34121504$
ट221 202 22120302
ट222 10531110101
211420121110301
1222 202 ट1210302
ट221 $200 \quad 31110001$
$1127300 \quad 31110602$
$1127206 \quad 31120805$
2123207 32220202
$1124 \quad 404 \quad 34220504$
$2220406 \quad 21210805$
112310232210002
$2223200 \quad 21210502$
112220434120201
212020232110505
122320833210702
122320534110202
112430431310506
2122 100 32220502
$2121303 \quad 31110100$
$1125200 \quad 34140701$
222730634121506
221420431120601
$1123200 \quad 34140201$
122320633120602
2226 10233140102
112520331120602
2210 $102 \quad 33120602$
$1125 \quad 10321140001$
$2121 \quad 103 \quad 31220401$
121320332120301
$2124 \quad 100 \quad 22111701$
2220 $100 \quad 33110001$
2114 202 12220401
122650032121003 
29011152324212221 29213132324111211 29412131320222222 30011152326221 221 उ०211152322221 222 30621142321221 222 30713152322221222 30811142321221222 30921152326222222 31013152326221222 311161326221222 312 151320222122 31320141320222122 31423141 3222 1 222 1 31510161320221122 31611141323221221 31221141 322211221 उ1822152321121222 31911152321221221 32011152320222222 32112152320221222 उ2210162321221222 32313161324221 222 उ2422162321 221 1222 उ2522151 326221222 32612151324212222 зе72315232221 222 1 उ2823141323221 1222 32923151323212 22 उ3021162322221 1222 33112141325221222 33213151322221222 उ3321151322221 222 उ3421151326222222 33523141321 ट21 222 33610141321212222 33722152317221222 33810142321221221 33910152320222122 34023151321221 222 34112152321221 222 34212152322221222 34320152327211221 34411172426221222 34521 उ421ट21222 34623182421 221 222 34710181420222122 34810182423221222 34923171421221222 उ5022181420222122
212720022220501 11220512120302 $1224404 \quad 12310001$ 122520512120801 122320112120904 2210 50223120200 $2120 \quad 102 \quad 12110201$ ट210 20212120200 212220432110905 2122 20112320100 $2121 \quad 103 \quad 12110101$ 222050012340000 2220 $100 \quad 22140000$ 2122 302 22110203 $2210 \quad 101 \quad 120000$ $1212200 \quad 12310603$ 112320422120301 ट210 20022140102 2121 101 22220401 212120112220301 2210 202 22210001 ट211 102 12110000 $2120204 \quad 12110504$ ट210 202 22110001 122430222110003 2212 10112210102 2120 $200 \quad 22140403$ $1125 \quad 100 \quad 32140201$ 2212 $100 \quad 34120204$ 122220332120301 112220032240003 2210 $101 \quad 12120101$ 121210022120301 112210032110000 5120 $100 \quad 22120102$ ट210 20112310000 122210332120103 र211 202120000 टट20 $00 \quad 12520000$ $2211 \quad 107 \quad 34310302$ 2120 $300 \quad 12240204$ $2120 \quad 303 \quad 22210207$ $1126 \quad 303$ 22 0000 $2120 \quad 10212120300$ 2211 202 23120200 ए121 10232120001 2220 30013240000 212030112210000 $2211 \quad 100 \quad 33110101$ 222010233110001 
उ5121 उ427221 उ5222 1 82424221 1 222 3532318142322 1 1.22 35423182424221221 उ5522181421 221 222 35621171427212222 35720182423221 1222 35813182421 221 222 3591192424221222 $3602318 \quad 421221222$ 36112171421 ट21 ट21 उ6221171425221 1222 36312182420222222 36412 2420221222 36520182424221 222 36611 2423221222 36721 182422221 222 36913171423221 222 3692318142121 2222 37010191420222122 371 201714202221 122 37221191423221221 उ7821182422221 222 3742018 421221221 37513182427111211 37622181427221 221 37722181420221 222 37810181420222122
$2121 \quad 101 \quad 33110201$

$2120 \quad 10132120104$

ट250 20133120002

ट221 200 22120201

2211 200 32210002

ट120 102 32120100

2122203320000

2122 1011 2220304

$2124 \quad 105 \quad 32120601$

$2120 \quad 100 \quad 22120101$

2220 10232340002

2121 101 22120202

$2210200 \quad 32340003$

122120012140001

2121202 22 0000

$2124100 \quad 12220401$

$122 \quad 102$ 22120100

2123508 32220101

$2211 \quad 101 \quad 33120201$

2220 50012210000

ट220 501 ट2110000

ट222 202 22120101

$2120 \quad 10133120200$

2220 20232120000

$1127 \quad 410 \quad 12331815$

1122 202 32120102

ट210 02 32110002

2220 $100 \quad 12120000$ 
R E FERENCES 


\section{BIBLIOGRAPHY}

Almeida, P. M. (1977). Children's television and modeling of pro behaviors. Education and Urban Society, 10, 55-66.

Alloway, L. (1972). Violent America: The movies 1945-64. New York: Musem: of Modern Art.

Anderson, D. R., \& Levin, S. R. (1976). Young children's attention to "Sesame Street." Child Development, 47, 806-811.

Bachan, C. M., Horriby, M. C.; Roberts, D. F., \& Hernandez-Ramos, P. F. (1982, March 19). Television viewing behavior and the development of reading skills: Survey evidence. Paper presented at the annual meeting of the American Educational Research Association.

Ball, S., \& Bogatz, G. A. (1970). The First Year of Sesame Street: An evaluation. Educational Testing Service. Princenton, N. J.

Bandura, A., Ross P., \& Ross, A. A. (1963). Imitation of film mediated aggression models, Journal of Abnormal and Social Psychology, $\underline{66}, 3-11$.

Bandura, A. (1965). Vicarious process: A case of no-trial learning. In L. Berkowitz (Ed.), Advances in Experimental Social Psychology (Vol. 20). New York: Academia Press.

Bandura, A. (1973). Social learning theory. Englewood Cliffs, N. J.: Prentice Hall.

Baron, L. (1980). What do children really see on television? Montreal, Canada: Concordia University. (ERIC Documental Reproduction Service, No. ED 188 784).

Belson, W. (1978). Television violence and the adolescent. Westmead, England: Jaxom House, Tearfield.

Boblick; T. \& Howicki, A. (1984). The incidence of external locus of control in televised cartoon characters. The Journal of Genetic Psychology, 144, 99-104.

Brown, M H., Skeen, P., \& Osborn, D. K. (1979). Young children's perception of the reality of television. Contemporary Education, 50, 129-133. 
California Assessment Program (1982): Survey of sixth grade school achievement and television viewing habits. Sacramento, CA: California State Department of Education

Cisin, I. H. (et al., 1972). Television and growing up: The impact of televised violence. Washington, D C: U. S. Government Printing office.

Cline, V. B., Croft, R. G., \& Courrier, S. (1974). The desensitization of children to T.V. violence. In V. B. Cline, (Ed.), where do you draw the line? (pp. 147-155). Provo: Brigham Young University Press.

Collins, W. A., Wellman, H., Keniston, A. H. A., \& Westby, S. D. (1978). Age-related aspects of comprehension and inference from a televised dramatic narrative. Child Development, 49, 389-399.

Comstock, G. (1977, Summer). Types of portrayal and aggressive behavior. Journal of Commination, 27, 109-198.

Conrad, R. (1972). The development role of vocalization in short-term memory. Joumal of Verbal Leaming and Verbal Behavior, 11, 521533.

Davidson, E. S., \& Neale, J. M. (1974). Analizing prosocial content on entertaiment television. Paper presented of the 82th Annual Convention of the American Psychologycal Assn., New Orleans.

DeVries, R. (1969). Constancy of genetic identity in the years three to six. Monographs of the Society for Research in Child Development, 4. 34 .

Drabman, R. S., \& Thomas, M. A. (1974). Does media violence increase children's toleration of real-life aggression? Developmental Psychology, 10, 418-421.

Ellis, G. T. \& Sekyra, F. (1972). The effect of cartoons on the behavior of first grade children, Journal of Psychology, 18, 37-43.

Eron, L. D., Lefkowitz, M. L., \& Heusmann, L. R. (1972). Television violence and child aggression. A follow-up study. In G. A. Comstock, \& E. A. Rubinstein (Eds.), Television and social behavior: Vol. 3. Television and adolescent aggressiveness. Washington, D C: U. S. Goverment Printing Office.

Eron, L. D., Lefkowitz, M. L., \& Heusmann, L. R. (1977). Growing up to be violent: A longitudinal study of the development of aggressions. New York: Pergamon.

Eron, L. D., Heusmann, L. R. (1984). Paper presented on panel The Social Impact of Television Violence. Symposium on Media Violence and Pomography, Toronto, Ontario, Canada. 
Feshbach, S. (1976). The role of fantasy in the response to television.

Fontes, B. F. (1978). Parent and adult mediation of television programing and peer presence: Their effects on children. Dissertation Abstracts International, 39, (1A)8.

Freud, S. (1963). Jokes and their relations to the unconscious. Translated from the German and edited by James Strackey. New York: Morton. (First published in 1905.)

Friedrich, L. R., \& Stein, A. H. A. (1973). Aggressive and prosocial television programs and the natural behavior of preschool children. Monographs of the Society for Research in Child Development, 33 (4), serial No. 151 .

Gerbner, S. (1972). Violence on television drama: Trauma and symbolic functions. In G. A. Comstock and E. A. Rubinstein (Eds.). Television and social behavior. Vol.1. Media content and control (pp. 28-187). Washington, D C.: U. S. Goverment Printing office.

Greenberg, B. A. (1969). The content and context of violence in the mass media. In R. R. Baker and S. J. Ball (Eds.), Violence and the media: A staff report to the National Commission on the Causes and the Prevention of Violence: (pp. 423-452). Washington, D C: U. S. Goverment Printing Office.

Hale, G. A., Miller, L. R., \& Stevenson, H. W. (1968). Incidental learning of film context. Child Development, 39, 69-77.

Hapkiewicz, W. G. \& Roden, A. H. (1971). The effect of aggressive cartoons on children's interpersonal play, Child Development, 42, 15831585 .

Hawkins, R. (1977). The dimensional structure of children's perception of television reality. Comminication Research, 3, 299-320.

Hayes, D. S. \& Bimhaum, D. W. (1980). Preschooler's retention of televised events: Is a picture worth a thousand words? Developmental Psychology, 16, 410-416.

Hayes, D. S., \& Schulze, S. A. (1977). Visual encoding in preschoolers' serial retention. Child Development, 48, 1066-1070. .

Hormick, R. (1981). Out-of-school television and schooling: Hypotheses and the methods. Review of Education Research, 51, 193-214.

Heusmann, L. R., Lagerspetz, K., \& Eron, L. D. (1980). Intervening variables in the television violence-aggression relation: Evidence from two courtries. Developmental Psychology, 20, 146776. Progress and Implications for the eighties (Vol.2.). Washington, D C: U. S. Government Printing Office. 
Jarrel1, S. (1982). Violence in children's cartoons. Department of Education National Institute of Education. Educational Resources Information Center. (ERIC, No. 222 329)

Koinlberg, L. (1968). Cognitive stages and preschool education. In J. L. Frost (Ed.), Early chilchood education rediscovered (pp. 212224). New York: Holt, Rinehar \& Winston.

Leifer, A. D., Gordon, M. J., \& Graves, S. B. (1975). Children's television: More than mere entertaiment. Harvard Educational Review, 44, 213-245.

Levine, D. J. \& Havighurst, R. J. (1984). Society and education (6th ed.). New York: Allyn and Bacon.

Lottan, S. (1967). The ability of children to distinguish between the "make believe" and the "real" in children's literaturc. Journal of Educational Thought, $\underline{1}, 25-33$.

Lovaas, O. I. (1961). Effect of exposure to symbolic aggression on aggressive behavior. Child Development, 32, 37-44.

Lyle, J. \& Hoffman, A. R. (1972). Children's use of television and other media. In E. A. Rubinstein, G. A., Comstock, and J. P. Murray (Eds.). Television and social behavior: Vol 4. Television in day-to-day life: Patterns of use (pp.1-320). Washington, D C: U. S. Goverment Printing OFfice.

Mattern, K. K. \& Lindholm, B. W. (1983). Effect of matemal commentary in reducing aggressive behavior. Impact of televised violence on preschool children. The Joumal of Genetic Psychology, 146 (1), 133-134.

McCarthy, E. D., Langren, T. S., Gersten, J. C., Eisenberg, J. G., and Orzeck, L. (1975). Violence and behavior disorders. Journal of Commanication, $25,71-85$.

McCoy, E. (1981, June). What television is doing to your kids. Parents, (pp. 55-80).

McGhee, P. E. (1975, April). Television as a source of learning stereotype sex roles. Paper presented at biennial meeting of the Society for Research in Child Development, Denver.

Miller, T. W. (1983). Identification process and sensory impact of children's television programing of the preschool child. Child Study Journal, 13, 203-207.

Noble, C. (1966). Reports on irternational evaluation on children's reactions to the Swedish television program "Patrick and Putrick." San Francisco: Bass. 
Piaget, J. (1966). The child's conception of physical casuality. London: Routledge and Regan Paul.

Pierce, C. M., Caren, J. V., \& Willis, D. (1977, November). An experiment in racism: TV commercials. Education and Urban Society, 10, 61-87.

Poulos, R. W., Rubenstein, L. A., \& Liebert, R. M. (1975, Auturm). Positive social learning. Journal of Cammication, 25, $90-$ 97.

Poulos, R. W., Harvey, S. E., \& Liebert, R. M. (1975). Saturday Morning Television: A profile of the 1974-75 children's season. Psychological Reports, 39, 1047-1057.

Rotter, J. B. (1954). Social learning and clinical psychology. Englewood, NJ: Prentice-Hall.

Siegel, A. R. (1955). Filiin ediated fantasy aggression and strength of aggressive drive. Child Development, 27, 365-378.

Singer, J. L., \& Siriger, D. G. (1980). Television, imagination and aggression: A study of preschoolers play. Hillsdale, $\overline{\mathrm{N}} \mathrm{J}$ : Erlbaum.

Stein, A. H. (1971). Mass media and young children's development. In N.I. Gordon (Ed.), Early childhood education. (pp. 181-202). New York: National Society for Education.

Stein, A. H., \& Friedrich, L. (1972). Television content and young children's behavior. In J. Murray, E. Rubinstein, \& G. Comstock (Eds.), Television and social behavior, 11, 202-317. Washington, D C: U. S. Goverment Printing Office.

Stein, A. H., \& Friedrich, L. R. (1975). Impact of television on children and youth. In E. M. Hetherington (Ed.). Review of child development research, 5, 222-223. Univ. of Chicago Press.

Steinfeld, J. (1975). Report to United States Senate Subcomittee to Investigate Juvenile Delinquency. Our nation's schools-- A report card: "A" in school violence and vandalism (pp. 221223). Washington D C: U. S. Goverment Printing Office.

Stevenson, H. W. (1972). Television and the behavior of preschool children. In J. P. Murray, E. A. Rubinstein, \& G. A. Constock (Eds.). Television and social behavior: Vol.2. Television and social leaming (pp. 1-42). Washington: D C: U. .S Goverment Printing office.

Steuer, F. B., Applefield, … D., \& Smith, R. (1971). Televised aggression and the interpersonal aggression of preschool children. Journal of Evperimental Child Psycholngy, 11, 442-447. 
Susman, E. J. (1978). Visual and verbal attributes of television and selective attention in preschool children. Developmental Psychology, 14, 565-566.

Taylor, B. \& Howell, R. (1973). The ability of three, four, and fiveyear-old children to distinguish fantasy fron reality. Joumal of Generic Psychology, 12, 315-318.

Turrow, J. (1981). Entertaiment, education, and the hard sell. Three decades of network children's television. New York: Praeger.

United States Congress Senate Hearings (1972). Report to the Surgeon Coneral on television violence. Washington, D C: U. S. Coverment Printing office.

United States Department of Health and Human Services (1972). Television and behavior. Ten years of scientific progress and implications for the eighties. Vol. 1: Summary Report. Washington, D C: U. S. Goverment Printing Office.

United States Public Health Service, Panel of Scientists (1982). Report to the Surgeon General on television violence. Washington, D C: U. S. Goverment Printing office.

Vard, S., \& Wackman, B. D. (1973). Children's attention to television and advertising. In E. A. Robinson, G. A. Comstock, \& J. P. Murray (Eds.), Television and social behavior (Vol. 4). Washington, D C: U. S. Goverment Priníizg Office.

Wilke, J. (1985, March). Are the programs your kids watch simply commercials? Business Week, March 25, p. 53-54.

ivilliams, M. (1978). Differential impact of TV on children: A natural experiment in commuities with and without TV. Paper presented at the meeting of the International Society for Research on Aggression. Washington, D C.

Winn, M. (1977). The plug-in drug: Television, children, and the family. New York: Viking.

Zuckeman, M., Ziegler, M. \& Stevenson, H. .W (1978). Children's viewing of television and recognition of comercials. Child Development, $49,96-104$. 